\title{
Uluslararası Basın Fotoğrafçılığının Ürettiği Dünya İmgesi: WPP Ödüllü Fotoğraflar Üzerinden Bir Okuma
}

DOI: $10.26466 /$ opus.798661

$*$

\author{
Onur Dursun * - Filiz Y1ld1z ** - Serkan Bulut *** \\ * Doç.Dr., Çukurova Üniversitesi İletişim Fakültesi Gazetecilik Bölümü \\ E-Posta: dursunonur@gmail.com \\ ORCID: $0000-0001-9268-0936$ \\ ** Dr.Öğr.Üyesi, Çukurova Üniversitesi İletişim Fakültesi Gazetecilik Bölümü \\ E-Posta: filizyildiz@cu.edu.tr \\ ORCID: $\underline{0000-0002-1206-4314}$ \\ ***Ar.Gör.Dr., Çukurova Üniversitesi İletişim Fakültesi Gazetecilik Bölümü \\ E-Posta: serkanbulut@cu.edu.tr \\ ORCID: $\quad \underline{0000-0001-8252-5262}$
}

\begin{abstract}
Öz
Bu çalışma World Press Photo (WPP) adlı kuruluş tarafindan ödüllendirilen fotoğrafları analiz ederek uluslararası basın fotoğrafçılı̆̆ı alanının habitusu çerçevesinde oluşan dünya imgesine odaklanmaktadır. Çalışmanın analizi 4 kategoriden oluşmaktadır: (1) ödüllendirilen fotoğraflar; (2) fotoğrafların çekildiği ülkeler, fotoğrafçıların uyrukları ve kıtaları; (3) fotoğrafları dünya çapında yayınlayan medya kuruluşlarının kökenleri; (4) WPP jüri üyelerinin uyrukları ve kıtaları. Bourdieu'nun alan, habitus ve sermaye/sermayeler kavramlarına dair teorik çerçevesi üzerinden elde edilen bulgular medya profesyonellerinin/foto muhabirlerinin, Kuzey Amerika ve Avrupa gibi Batı kökenli medya kuruluşlarında çalıştıklarını, bu medya kuruluşlarınca yayınlanan ödüllü fotoğraflarda Afrika, Asya, Orta ve Güney Amerika'nın savaş, çatışma, terör, hastalık, açlık/yoksulluk, kadınlara ve çocuklara yönelik şiddet, kötü yaşam koşulları ve hak ihlalleriyle temsil edildiğini ortaya koymaktadır. Bu temsilleri onaylayanlar da Batı merkezli bir kuruluşun (WPP) Batılı jüri üyeleridir. Özetle bu çalışma Batı'nın (Kuzey Amerika ve Avrupa) özne poziyonundaki coğrafyalar olarak üretildiğini dünyanın geri kalanının ise (Avustralya hariç) nesne konumuna yerleştirildiğine dair bir tartışma yürütmektedir.
\end{abstract}

Anahtar Kelimeler: basin fotoğrafçılı̆̆ı, medya, WPP, dünya imgesi, Bourdieu, alan ve habitus 


\title{
The World Image Produced by International Press Photography: A Reading Through the Awarded Photos by World Press Photo Foundation
}

\begin{abstract}
This study focuses on the image of the world set by the habitus/practices of the international photojournalistic field by examining the photos awarded by the World Press Photo Foundation (WPP). The analysis consists of four categories: (1) the awarded photos; (2) the countries where the photos were taken and the nationalities and continents of the photographers; (3) the origins of the media organizations that publicize these photos around the world; (4) the nationalities and continents of the jury members of the WPP contest. Through a theoretical framework of Bourdieu's concepts such as field, habitus and capital(s), the findings reveal that the media professionals/photo-journalists working in the West-originated (those in North America and Europe) media organizations represent Africa, Asia, Central and South America as the centers of war, conflict, terror, disease, famine/poverty, violence against women and children, unfavorable living conditions, abuse of rights. These representations are also approved by Westerners jury members in a Eurocentric Foundation (WPP) To sum up, this study argues that the West (Europe and North America) is produced as a place with a subject position while the rest of the world (except for Australia) is generally placed in an object position.
\end{abstract}

Keywords: photo-journalism, WPP, image of the world, Bourdieu, field and habitus 


\section{Giriş}

Bireylerin dünyada meydana gelen olayları algılamaları ve anlamlandırmalarında medya önemli rol oynamaktadır. Gündelik yaşam pratikleri, medya tarafından belirlenmekte, dünyada kültürel olan her şey medya tarafından inşa edilmekte, gerçeklik medyadaki haberlerle belirli bir çerçeve içerisinde sunulmaktadır (Tuchman, 1978, s.1; Luhmann, 1993, s.775). Toplumların gündemleri medya tarafından oluşturulmaktadır (Lippmann, 1922; McCombs ve Shaw, 1972, 1993; McCombs, 2005). Uluslararası ölçekte ise dünya gündemi gelişmiş ülkeler tarafından belirlenmekte daha ötesi insanlığın kaderi bu devletler aracılığıyla çizilmektedir. İnsanlık tarihi boyunca bitmeyen savaşlar, soykırımlar, katliamlar, göç, yoksulluk gibi acı barındıran nice olayın aktörünün güçlü devletler olduğunu söylemek yanlış olmayacaktır. Daha açık ifade edecek olursak uluslararası dinamikleri, 'moderndemokratik Batı' için tehdit olarak görülen ve bu nedenle de müdahale edilmesi gereken anti-modern/anti-demokratik Doğu algısı şekillendirmektedir (Said, 1997, s. 3-34). Bu doğrultuda Doğu'ya yönelik acımasız müdahale ve eşitliksiz eylemler uluslararası medyanın da gündemini oluşturmakta, medya profesyonelleri açısından başta Asya ve Afrika olmak üzere dezavantajlı bölgelerde savaş, çatışma, terör, hastalık, sefalet, kadına ve çocuğa yönelik şiddet gibi çok çeşitli yollardan ama aynı şeyi anlatan ortak bir bilinç/bir habitus oluşmaktadır.

İbn-i Haldun'un 'Coğrafya Kaderdir' sözünün günümüzde her şeyden önce kültürel bir karşılığı bulunmaktadır. Hatta coğrafya kadere dönüştürülmüştür. Clark (2000, s. 35-36), zenginliği ve gücü elinde bulunduranların, Voltair' in "tarih, üzerinde uzlaşıya varılmış bir kurgudur" düşüncesini doğrularcasına davranarak dünyanın koşullarını ve gelişmelerini kurguladıklarını ve bunu da denetim altında tuttukları medyanın gücüyle birleştirdiklerini ifade etmektedir. Chomsky (1989, s. 269) de Necessary Illusions'da tarih mühendisliğinin tarih kadar eski olduğunu ve ABD'nin 1. Dünya Savaşı́na girmesiyle bunu mesleki bir sorumluluk olarak üstlendiğini vurgulamaktadır. Tarihi kurgulayanlar dünyayı yönetmekte ya da dünyayı yönetenler tarihi kurgulamaktadır. Böylece dünyanın söylemi, belirli güç merkezlerinde belirli bir sistematik dahilinde üretilmektedir (Foucault, 1981).

Bu çalışma uluslararası basın fotoğrafçılığı alanında prestijli bir kuruluş olan World Press Photo tarafından ödüle layık görülen fotoğraflar üzerin- 
den Doğu-Batı imgesini ortaya koymayı amaçlamaktadır. Dünya genelinde foto muhabirleri tarafından karelenen ödüllü fotoğraflar aracıllğıyla dünyadaki güç/iktidar ilişkilerinin, fırsat eşitsizliklerinin, yaşanılan coğrafyaya özgü talihsizliklerin, kültürel farklılıkların ve daha önemlisi Batı nezdinde Doğu'nun okunabileceği düşünülmektedir. Çalışma, medyanın haber konularına/olaylara yaklaşma biçimini, haber değeri algısını, basın fotoğrafçlığı reflekslerini ve uluslararası medya kuruluşlarının dünya genelindeki hegemonyasını göstermesi bakımından önem taşımaktadır. Yapısal unsurları görmezden gelerek medya profesyonellerinin çalışmalarına odaklanmak sonuca ulaşmada yetersiz kalacaktır. Zira toplumsal alanda var olan şey, öznelerarası bağlar ya da etkileşimler değil, Marx'ın da dile getirdiği gibi "bireysel iradelerden ve bilinçlerden bağımsız" nesnel bağlantılardır (Bourdieu, 2014, s. 81). Bourdieu (2010, s.42; 1998a, s.38), gazeteciler hakkında değil de gazetecilik hakkında konuşmayı doğru bulur. Gazeteciler hakkında konuşmak, suçu gazeteciye yüklemektir. Gazetecilik hakkında konuşulduğunda ise tartışma gazetecilik alanının iş yapma pratiklerine/habitusuna yönelmiş olur.

$\mathrm{Bu}$ çalışma incelenen fotoğraflarla ilgili daha sağlıklı ve nesnel sonuçlara ulaşabilmek ve durumu foto muhabirlerinin tutumlarından kısmen bağımsızlaştırarak, uluslararası iktisadi ve siyasi politikalarla bağlantılı uluslararası media/gazetecilik alanının pratikleri olarak değerlendirebilmek için Bourdieu'nün alan ve habitus, yer yer de kültürel sermayelüretim ve sembolik sermaye/güç kavramlarına başvurmuştur. Bourdieu'ye (1998a, s.69; 2010, s.3337) göre gazetecilikte nelerin olduğunu anlamak için, yayının maddi anlamda kimlerce desteklendiği, kimlerin reklamcı olduğu, sübvansiyonların nereden geldiği gibi durumları bilmenin yanı sıra gazetecilik alan olarak kavramsallaştırılarak içsel ve dışsal bağlantılarıyla birlikte irdelenmelidir. Bu bakış açısından hareketle çalışma kapsamında incelenen fotoğraflar uluslararası basın fotoğrafçılığı alanının habitusunun bir sonucu olarak ele alınmış ve uluslararası politikalarla ilişkili uluslararası medya/gazetecilik alanın habitusuyla (habitusların ortaklığından dolayı) paralel irdelenmeye çalışılmıştır. 


\section{Kuramsal Ardalan: Uluslararası Politikalarla İlişkili Uluslararası Medya/Gazetecilik Alanının Yapısı}

Uluslararası medyayı inceleyen çalışmalar ABD medyasına odaklanmaktadır. Bunun nedeni uluslararası alanda güçlü medya kuruluşlarının ABD merkezli oluşudur. Çalışmaya dahil edilen 574 fotoğrafın 509'unu kareleyen muhabirlerin hangi yayıncı kuruluşlarca yetkilendirildiği irdelendiğinde 528 yayıncı kuruluştan 264'ünün ABD kökenli olduğu görülmüştür. Foto muhabirlerinin uyruklarına bakıldığında da ABD'nin açık ara ilk sırada yer aldığı dikkat çekmektedir. Bagdikian The New Media Monopoly (2004, s.10-30; Warf, 2007) kitabında dünyanın iletişim akışını kontrol altında tutan büyük medya tekellerinin ya ABD kökenli olduğu ya da bu tekellerin diğer ülkelerin medya tekelleriyle çeşitli şekillerde ortaklığının bulunduğu bilgisini vermektedir. Forbes'in “World's Biggest Media Companies" 2015 listesinin ilk 10'unda 8 ABD, 1 Birleşik Krallık ve 1 Kanada kökenli medya şirketi yer almaktadır. Bu şirketler sırasıyla şöyledir: Comcast (ABD), Walt Disney (ABD), Twenty-First Century Fox, Inc. (ABD), Time Warner (ABD), Time Warner Cable (ABD), Directv (ABD), CBS (ABD), Viacom (ABD), British Sky Broadcasting (Birleşik Krallık), Thomson Reuters (Kanada). Almanya (Bertelsmann) ve Avustralya (News Corp.) gibi ülkelerin medya şirketleri de -ABD kadar olmasalar da- uluslararası medya alanında söz sahibi ülkeler listesinde yer almaktadır. Bu ülkeler iletişim politikaları ile diğer ülkelerin iletişim politikaları üzerinde egemenlik kurarak küresel iletişimi belirlemekte ve yönetmektedir (bkz. Thussu, 2000, s.11-52; Arsenault ve Castells, 2008). Bu nedenle uluslararası medyanın bir alan olarak habitusunu belirlemek az sayıdaki güçlü Batı merkezli ülke medyasının uluslararası politikalarıyla paradigmalaşmış liberal/ana akım medya (Hallin ve Mancini, 2004; Gencel Bek, 2010, s.107) alanının habitusunu belirlemek anlamına gelmektedir.

Dünya gündemini belirleyen güçlü medya kuruluşları, haberlerinde bağlı oldukları devlet güdümünde yapılandırılan gerçeklikleri birtakım süzgeçlerden geçirerek toplumların ya da dünyanın gündemini oluşturmaktadır (Tuchman, 1978, s.196; Hallin, 1986; Chomsky, 1989, s.106; Herman ve Chomsky, 2008, s.1-33; Gans, 2003, s.52-54; 1980; McChesney, 2006, s. 149152; Schudson, 2010, s. 215-216; 1989, s. 12; Firmstone, 2012). Örneğin silah tacirleri ve $\mathrm{ABD}$ yönetimince yönlendirilen ABD medyası, ABD'nin Irak'1 istilası sürecinde halkın savaşa dair algısını, bu güç merkezlerinin istekleri 
doğrultusunda şekillendirmiştir. The Washington Post'un yaptığı anket, ABD halkının \%69'unun 11 Eylül saldırısının Saddam Hüseyin tarafından gerçekleştirildiğine inandığını ortaya koymuştur (İnceoğlu, 1997, s.86-87). Irak Savaşı da Pentagon direktiflerini takip eden medya aracılığıyla halk düzeyinde normalleştirilerek gerekli bir müdahale olarak yansıtılmıştır (Schechter, 2003, s.15-27). ABD ve İngiltere gibi ülkeler, terörle mücadelede medyayı ulusal çıkar söylemi doğrultusunda kullanabilmektedir (Mughan ve Gunther, 2000, s.4-6; Gencel Bek, 2010, s.105). ABD medyasının devlet tarafından yönlendirildiğini birçok çalışmasında dile getiren Chomsky (1989, s.233), hükümetlerin medya ile paylaştıkları bilgilerin gazeteciler tarafından çoğunlukla sorgusuz sualsiz kabul edildiğini ileri sürmektedir.

Chomsky and Herman (2008), ABD medyası üzerinden geliştirdikleri propaganda modelinde de ABD medyasının haber üretim pratiklerini yönlendiren çeşitli mekanizmalardan söz etmektedirler. Chomsky ve Herman'a göre bir olayın ABD medyasında haber olarak yer alabilmesini sağlayan 5 filtre mevcuttur. Bu filtreler ABD medyasını, ABD'nin ulusal ve uluslararası politikaları doğrultusunda da şekillendirmektedir:

(1) Egemen medya kuruluşlarının büyüklüğü, mülkiyet yoğunlaşması, patronların serveti ile kâr odaklılığı (2) Kitle medyasının başlıca gelir kaynağı olarak (3) medyanın devlet ve iş dünyası ile bu temel kaynaklar ve güç odakları tarafından fonlanan ve onaylanan uzmanların sağladığı enformasyon (4) medyayı disipline etme aracı olarak tepki üretimi (5) Ulusal bir din ve denetim aracı olarak komünizm karşıtlığ (Herman ve Chomsky, 2008, s. 1-2).

Dünya genelinde ulusal ve uluslararası çıkarlar haber akışlarıyla birleşerek, güçlü biz-zayıf onlar temelli çatışmalı dünya imgesini sürekli canlı tutmaktadır. Galtung and Ruge (1965), Norveç'te yayımlanan günlük 4 gazetenin Kıbrıs, Küba ve Kongo bunalımlarıyla ilgili haberleri örneğinde yaptıkları çalışmada ekonomik ve kültürel açıdan güçlü ulusların yüksek haber değerine sahip olduklarına ve bu ulusların gücü, refah düzeyi ve başarılarıyla gündeme geldiklerine işaret etmektedirler.

Uluslararası alanda güçlü olan medya kuruluşları, bağlı oldukları güç merkezlerinin propagandasını yaparken, güçsüzleri de karşı kutba yerleştirmekte ve bu iki kutup arasındaki zıtlıktan yararlanarak hem haber/içerik üretmektedir hem de belirli taleplere göre kültürel bir dünya haritası çizmektedir. 


\section{Çalışmanın Yöntemi ve Örneklemi}

Bu çalışma WPP üzerinden uluslararası basın fotoğrafçılığı alan pratiklerine ve böylece oluşan dünya imgesine odaklanmıştır. WPP'nin ödüllendirdiği fotoğraflar aracılığıyla yeniden üretilen dünya imgesi, birbiriyle bağlantılı aşamaların sonucunda oluşmaktadır. Şöyle ki, liberal habercilik anlayışına göre bir fotoğrafın dezavantajlı bir coğrafyada olumsuz ve/veya şiddete vurgu yapan bir içeriğe sahip olması ödül alma ihtimalini güçlendirmektedir. Bir konu genel olarak Batılı bireyler tarafından keşfedilerek kayıt altına alınmakta ve çoğunlukla Batı merkezli bir yayın kuruluşu tarafından yayımlanmaktadır. Son aşamada ise Batı merkezli/habituslu WPP devreye girerek tespit edilen durum üzerinden tespit edeni ödüllendirerek ona 10.000 Euro gibi iktisadi sermaye, ilişkiler ağına dahil ederek sosyal sermaye ve saygınlık kazandırarak da sembolik güç/sermaye yüklemektedir (Bourdieu, 1986).

Yukarıda aktarılan süreç bu çalışmada 4 başlık altında irdelemiştir. Bu başlıklar çalışmanın izleğini ifade etse de aslında uluslararası basın fotoğrafçllı̆̆ının ve doğal olarak uluslararası medyanın işleyişine ilişkin bir modele de karşıllk gelmektedir. Süreci oluşturan başlıklar şöyledir:

1. Fotoğrafların tutumu, durumu ve coğrafyası

2. Fotoğrafları kareleyen muhabirlerin uyrukları, ülkeleri ve kıtaları

3. Fotoğrafların yayınlandığı medya organizasyonları ve menşei ülke ve kitalar1

4. Fotoğrafları ödüllendiren jürilerin uyrukları, ülkeleri ve kıtaları

Çalışmanın örneklemini WPP'nin ödül kategorileri oluşturmaktadır. WPP 1955 ten günümüze toplamda 42 kategori altında yüzlerce fotoğrafi ödüllendirmiştir. WPP, ödüllerini "Photo of the Year" kategorisi gibi birkaç kategori dışında genel olarak "Singles" ya da "Stories" kategorileri altında birincilik, ikincilik ve üçüncülük şeklinde vermektedir. Kuruluş "Singles" kategorisinde bir fotoğrafı, "Stories" kategorisinde ise fotoğraf serilerini ödüllendirmektedir. Bu çalışmada, temaların çalışmayı yönlendirmemesi ve nicel analizlerin sağlıklı biçimde gerçekleştirilebilmesi için tematik olmayan kategorilerin "singles" ödülleri analiz edilmiştir. Tematik olan tüm kategoriler ile sadece "stories" ödülü veren kategoriler örneklem dışında tutulmuştur. "Singles" ve "stories" ödüllerinin her ikisini birden barındıran kategorilerin ise yalnızca "singles" ödülleri dikkate alınmıştır. Ödüllerin 
verilmeye başlandığ 1955 yılından 2018 yılına kadar 19 ana kategori altında 611 fotoğraf tespit edilmiştir. Bu fotoğrafların 7'sinin görseli WPP koleksiyonunda olmadığından analiz edilen fotoğraf sayısı 604 olarak belirlenmiştir. Ancak "Photo of the Year" kategorisi, tüm kategoriler içerisinde seçildiği için, incelenen kategorideki 28 fotoğrafla kesiştiği görülmüş ve bu durumda sadece ana kategorideki fotoğraf dikkate alınmıştır. Böylelikle "Photo of the Year" kategorisinde günümüze kadar ödül alan 60 fotoğrafın 28'i (aynı fotoğraflar olmalarından dolayı) analiz dışında tutulmuş ve bu kategoride 32 fotoğraf analize dâhil edilmiştir. Ayrıca bir fotoğraf "Budapest Award" and "General News" adlı iki kategoride birden ödül aldığı için bu fotoğraf sadece Budapest Award kategorisinde dikkate alınmıştır. Aynı şekilde bir fotoğraf da hem "Features" kategorisinde hem de "Public's Favorite" kategorisinde ödül aldığı için yalnızca "Features" kategorisi dikkate alınmıştır. Özetle çalışmada 19 kategori altında 574 fotoğraf analize tabi tutulmuştur. Araştırma bulguları takip eden 4 ana başlık altında, teorik bilgilerle değerlendirilerek sunulmuştur.

\section{Bulgular}

\section{Fotoğrafların Tutumu, Durumu Ve Coğrafyası: Uluslararası Fotoğrafçılık} Alanında Değerli Olan Nedir?

Uluslararası gazetecilik alanı, büyük ölçüde liberal paradigmanın haber anlayışını takip ettiğinden uluslararası basın fotoğrafçıllğı alanı da bu paradigmanın habitusunu taşımaktadır. Bu habitus dünyayı Doğu ve Batı ile Kuzey ve Güney şeklinde iki kere ikiye bölmektedir. Küresel iletişim akışı da ya Kuzey'den Güney'e ya da Batı'dan Doğu'ya şeklinde tarif edilmektedir (Płudowski, 2006, Hamelink, 2015). Hamelink (2015, s. 14) durumu, "Küreselleşme sıklıkla Batı'dan dünyanın geri kalanına aktarımdır" şeklinde özetlemektedir. Haber değeri açısından bazı konular, bazı kıtalar ve hatta bazı ülkeler ile özdeşleştirilmiş durumdadır.

Haberin yaşanan gerçekliği yeniden inşa ettiği düşüncesi eleştirel kuramın temel savı olsa da liberal çoğulcu kuramın da zaman zaman dillendirdiği bir düşüncedir (Poyraz, 2002, s. 62). Östgaard (1965), uluslararası haberlerde içeriğin bozularak diğer milletler hakkında basmakalıp değer yargılarının oluştuğunu, ulusların birbirleriyle iyi ilişkiler kurmalarının ve barış içinde yaşamalarının engellendiğini söylemektedir. Östgaard'a göre, devlet- 
lerin eylemleri uluslararası mevkilerinden çok kendi aralarındaki ilişkilere dayanmakta ve kalıp yargılardan etkilenmektedir. Kepplinger and Weissbecker (1991) ise, olumsuzluk gibi bazı haber değeri unsurlarını ideolojiyle ilişkilendirirken gelişmiş ülkelerin, az gelişmiş ya da gelişmekte olan ülkelerdeki olumsuzlukları öne çıkartacak şekilde eğilim gösterdiklerini söylemektedir. Çevre ülkelerde meydana gelen olaylarla ilgili olumsuz içerikler ağırlık kazanırken, olumlu dış haberler bilinçli bir şekilde ihmal edilmekte, görmezden gelinmekte, ayıklanmakta, elenmekte, saf dışı bırakılmakta ya da bilinçli olarak çarpıtılmaktadır.

Bourdieu'nün (1998a, s.19), gazetecilerin bazı olayları gören bazılarını ise görmeyen 'özel gözlükler' kullandığı şeklindeki metaforu bu noktada oldukça anlamlıdır. Gazeteciler bu gözlüklerle, olayları belirli açılardan görme, ayıklama ve birtakım formlara yerleştirme yeteneği sergilerler. Parenti (2000, s. 53) de benzeri bir vurguda bulunarak, en etkili propaganda biçiminin yalan söylemekten ziyade, durumu şekillendirmek olduğunu belirtir. Parenti, iletişim profesyonellerinin, vurgulama ve süsleme gibi çeşitli yöntemlerle gerçeklikten uzaklaşılmadığı hissi yaratarak istedikleri etkiye ulaştıklarını ifade eder. Bunu da haberin biçimsel-teknik özelliklerini kullanarak yaptıklarını söyler. Bu süreci gazetecinin kendisi yönetiyor gibi görünür ama aslında süreci gazetecilik alanı yönetir. Gazeteciye düşen oyunu kuralına göre oynamaktadır ama yine de bu, gazeteciyi tümüyle masum kılmaz. (Bourdieu,1998b, s.77).

Yapılandırılmış uluslararası bir iletişim akışının iş yapma pratikleri de yapılandırılmıştır. Bu pratikler alanın/oyunun kurallarıdır; alandaki yetkinlerin oyunu devam ettirebilmek ve alana yeni girenlerin ise oyuna dahil olabilmek için zorunlu olarak edindikleri kurallardır. Bourdieu, habitusu açıklarken 'oyun' metaforuna sıklıkla başvurur ve eyleyenlerin oyunlarda başarılı olmasını habitusu edinme ve kullanma yetilerine bağlar. Ona göre oyunların tümü, kendi kurallarını barındıran yapılandırılmış alanlardır (Bourdieu, 1998b, s.77). Alanda hareketi sağlayan failler alanda oyunu nasıl oynayacaklarına ilişkin hissiyatı, alandaki eylemler/pratikler sonucunda edinmişlerdir (Kaya, 2007, s.403). Zaten Bourdieu, pratik duygusunun, toplumsal olarak oluşturulmuş bir oyun duygusunun ürünü olduğu düşüncesindedir ve pratiklerin gerçek nedenlerinin ancak bu şekilde açığa çıkartılabileceğini düşünmektedir (Bourdieu ve Wacquant, 2014, s.110). Toplumsal oyunlara katılmak salt bilinçli bir eylem değil; üzerine düşünülmeden yapı- 
lan bir şeydir, bu oyunlar bir şekilde dâhil olduğumuz oyunlardır (Calhoun, 2007, s.81). Bu yüzden gerçek nedenler ancak alanın habitusunun irdelenmesiyle açığa çıarılabilir. Çünkü habitus alandaki eyleyiciye ya da eyleyiciler kümesine ait pratiklerin tümünü hem yapılandırarak sistematik kılar hem de diğer yapılandırılmış yaşam tarzlarının pratiklerinden ayırır (Bourdieu, 1984, s.170).

İncelenen fotoğraflar, kuşkusuz habitusu iktisadi ve siyasi olarak güçlü olanlarca belirlenmiş bir alanın kültürel üretimleridir. Bu alan, uluslararası politikalarla bağlantılı uluslararası gazetecilik alanının alt alanı olarak nitelendirebileceğimiz uluslararası basın fotoğrafçıllı̆ı $\mathrm{ral} / \mathrm{ana}$ akım medyanın üretim pratiklerini takip ettiğinden olumsuzluğa, şiddete değer atfetmekte ve böyle fotoğrafları Asya ve Afrika (Zarzycka ve Kleppe, 2013; Dursun, 2014; Kate, 2018) başta olmak üzere dezavantajlı bölgelerde kareleme eğilimi göstermektedir.

\section{Fotoğraflarn coğrafyası}

Bu başlık altında, incelenen fotoğrafların karelendiği ülke ve kıta bilgileri kodlanmıştır. Ödül alan fotoğrafların çekildiği ülkeleri belirten veriler Tablo 1'de yer almaktadır. 63 yıllık süreçte çeşitli dallarda ödül almış fotoğrafların kıtalara göre dağılımına (Tablo 2) bakıldığında sayısal olarak 235 (\%42,42) fotoğraf ile Asya kıtasının ilk sirada yer aldığı görülmektedir. Asya'yı 123 $(\%$ 22,20) fotoğrafla Avrupa izlerken, üçüncü sırada 77 (\% 13,90) fotoğrafla Afrika yer almaktadır. Kuzey Amerika'da karelenen 69 fotoğraf ise $\% 12,45^{\prime}$ lik bir paya sahiptir. 574 fotoğraftan ülkesi ve kıtası bilinmeyen 16's1 "Bilinmeyen" kategorisine yerleştirilmiştir. Dezavantajlı bölgeler olarak sıralayabileceğimiz Asya, Afrika, Orta ve Güney Amerika'da karelenen ödüllü fotoğrafların toplamı 362 iken avantajlı bölgeler olarak sıralayabileceğimiz Avrupa, Avusturalya ve Kuzey Amerika'da karelenen ödüllü fotoğraf sayısı 196'dır.

Tablo 1. Fotoğrafların ülkelere göre dağılımı

\begin{tabular}{|c|c|c|c|c|c|c|c|c|c|c|c|}
\hline Ülke & $\mathbf{N}$ & $\%$ & Ülke & $\mathbf{N}$ & $\%$ & Ülke & $\mathbf{N}$ & $\%$ & Ülke & $\mathbf{N}$ & $\%$ \\
\hline $\mathrm{ABD}$ & 67 & 11,67 & Haiti & 5 & 0,87 & Nijer & 3 & 0,52 & Arjantin & 1 & 0,17 \\
\hline Rusya & 35 & 6,10 & Italya & 5 & 0,87 & Romanya & 3 & 0,52 & Bolivya & 1 & 0,17 \\
\hline Filistin & 22 & 3,83 & Kenya & 5 & 0,87 & Somali & 3 & 0,52 & Burkina Faso & 1 & 0,17 \\
\hline Birleşik Krallık & 21 & 3,66 & Nijerya & 5 & 0,87 & İsveç & 3 & 0,52 & Burundi & 1 & 0,17 \\
\hline Almanya & 19 & 3,31 & $\begin{array}{l}\text { Güney } \\
\text { Afrika }\end{array}$ & 5 & 0,87 & Türkiye & 3 & 0,52 & Hirvatistan & 1 & 0,17 \\
\hline Vietnam & 19 & 3,31 & Kamboçya & 4 & 0,70 & Venezuela & 3 & 0,52 & Kibris & 1 & 0,17 \\
\hline
\end{tabular}




\begin{tabular}{|c|c|c|c|c|c|c|c|c|c|c|c|}
\hline Afganistan & 16 & 2,79 & Arnavutluk & 4 & 0,70 & Zaire & 3 & 0,52 & Cibuti & 1 & 0,17 \\
\hline Çin & 16 & 2,79 & Avustralya & 4 & 0,70 & Cezayir & 2 & 0,35 & Eritre & 1 & 0,17 \\
\hline Irak & 16 & 2,79 & Kolombia & 4 & 0,70 & Ermenistan & 2 & 0,35 & Finlandiya & 1 & 0,17 \\
\hline Bilinmeyen & 16 & 2,79 & Yunanistan & 4 & 0,70 & Avusturya & 2 & 0,35 & Gine & 1 & 0,17 \\
\hline İran & 12 & 2,09 & Guetemala & 4 & 0,70 & Kanada & 2 & 0,35 & İrlanda & 1 & 0,17 \\
\hline Suriye & 12 & 2,09 & Macaristan & 4 & 0,70 & Çad & 2 & 0,35 & Ürdün & 1 & 0,17 \\
\hline Hindistan & 10 & 1,74 & Kosova & 4 & 0,70 & El Salvador & 2 & 0,35 & Kurgizistan & 1 & 0,17 \\
\hline Küba & 9 & 1,57 & Myanmar & 4 & 0,70 & Israil & 2 & 0,35 & Letonya & 1 & 0,17 \\
\hline Sudan & 9 & 1,57 & Nikaragua & 4 & 0,70 & Kuveyt & 2 & 0,35 & Libya & 1 & 0,17 \\
\hline Fransa & 7 & 1,22 & Kuzey Kore & 4 & 0,70 & Liberya & 2 & 0,35 & Malavi & 1 & 0,17 \\
\hline Pakistan & 7 & 1,22 & Filipinler & 4 & 0,70 & Litvanya & 2 & 0,35 & Mali & 1 & 0,17 \\
\hline İspanya & 7 & 1,22 & Polonya & 4 & 0,70 & Malezya & 2 & 0,35 & Moldovya & 1 & 0,17 \\
\hline Brezilya & 6 & 1,05 & Ruanda & 4 & 0,70 & Moğolistan & 2 & 0,35 & Norveç & 1 & 0,17 \\
\hline Japonya & 6 & 1,05 & Uganda & 4 & 0,70 & Mozambik & 2 & 0,35 & Oman & 1 & 0,17 \\
\hline Lübnan & 6 & 1,05 & Angola & 3 & 0,52 & Peru & 2 & 0,35 & Portekiz & 1 & 0,17 \\
\hline Hollanda & 6 & 1,05 & Belçika & 3 & 0,52 & Surbistan & 2 & 0,35 & $\begin{array}{l}\text { Suudi } \\
\text { Arabistan }\end{array}$ & 1 & 0,17 \\
\hline Güney Kore & 6 & 1,05 & Şili & 3 & 0,52 & Tayvan & 2 & 0,35 & Sierra Leone & 1 & 0,17 \\
\hline Bangladeş & 5 & 0,87 & $\begin{array}{l}\text { Çek } \\
\text { Cumhuriyeti }\end{array}$ & 3 & 0,52 & Tayland & 2 & 0,35 & İsviçre & 1 & 0,17 \\
\hline Bosna-Hersek & 5 & 0,87 & Danimarka & 3 & 0,52 & Ukrayna & 2 & 0,35 & Tanzanya & 1 & 0,17 \\
\hline Kongo & 5 & 0,87 & Honduras & 3 & 0,52 & Yemen & 2 & 0,35 & Togo & 1 & 0,17 \\
\hline Misır & 5 & 0,87 & Endonezya & 3 & 0,52 & Yugoslavya & 2 & 0,35 & Tunus & 1 & 0,17 \\
\hline Etiyopya & 5 & 0,87 & Meksika & 3 & 0,52 & Zimbabwe & 2 & 0,35 & TOTAL & 574 & 100,00 \\
\hline
\end{tabular}

Tablo 2. Fotoğrafların Kıtalara Göre Dağılımı

\begin{tabular}{lll}
\hline Kita & N & \% \\
\hline Asya & 235 & 42,42 \\
\hline Avrupa & 123 & 22,20 \\
\hline Afrika & 77 & 13,90 \\
\hline Kuzey Amerika & 69 & 12,45 \\
\hline Orta Amerika & 31 & 5,60 \\
\hline Güney Amerika & 19 & 3,43 \\
\hline Avustralya & 4 & 0,72 \\
\hline Bilinmeyen & 16 & 2,89 \\
\hline
\end{tabular}

\section{Negatif Tutum}

Çalısma kapsamında öncelikle fotoğrafların tutumuna ilişkin bir inceleme yapılmıştır. 574 fotoğrafın imgelediği tutum olumlu, olumsuz ve nötr olmak üzere üç kategoride değerlendirilmiş ve $414(\% 72,13)$ fotoğrafın olumsuz, 94 $(\% 16,38)$ fotoğrafın olumlu, $64(\% 11,50)$ fotoğrafın ise nötr imgeli olduğu sonucuna varılmıştır (Tablo 3). Ülke ve kıta bilgisine ulaşılabilen 411 olumsuz imgeli fotoğrafın coğrafyaya göre dağılımı incelendiğinde Asya'nın $\% 46,38^{\prime}$ lik bir oranla ilk sırada, Afrika'nın \%17,15'lik bir oranla ikinci sırada yer aldığı sonucuna ulaşılmıştır. Avrupa ise \%15,70'lik bir oranla üçüncü sıradadır. Asya ve Afrika coğrafyalarında karelenen ve olumsuz içeriğe sahip fotoğrafların oranı toplandığında \%63,53 gibi yüksek bir rakama ula- 
şılmaktadır. Veriler, olumsuzluk içeren durumun/konunun daha fazla haber değeri taşıdığı (Galtung ve Ruge, 1965) düşüncesinin uluslararası basın fotoğrafçılığı alanınca da paylaşıldığını göstermektedir. Uluslararası basın fotoğrafçılığ1 alanın habitusunun başarı ölçütü/oyunun kuralı, objektifi olumsuz olana yöneltmektir.

Tablo 3. Olumsuz tutumun kıtalara göre dă̆ılımı

\begin{tabular}{lll}
\hline Kita & $\mathbf{N}$ & $\%$ \\
\hline Asya & 192 & 46,38 \\
\hline Afrika & 71 & 17,15 \\
\hline Avrupa & 65 & 15,70 \\
\hline Kuzey Amerika & 40 & 9,66 \\
\hline Orta Amerika & 25 & 6,04 \\
\hline Güney Amerika & 15 & 3,62 \\
\hline Avustralya & 3 & 0,72 \\
\hline Bilinmeyen & 3 & 0,72 \\
\hline
\end{tabular}

Fotoğrafların tutumunu kıtalar özelinde incelediğimizde Tablo 4'teki sonuçlara ulaşılmıştır. Tablo incelendiğinde Asya'nın temsil edildiği 235 fotoğraftan $192(\% 81,70)$ 'sinin, Afrika'nun temsil edildiği 77 fotoğraftan ise $71(\% 92,21)$ 'inin olumsuz imge taşıyor oluşu dikkat çekmektedir. Afrika'dan nötr tutum içeren fotoğrafa rastlanmamıştır. Bu coğrafyalara dair olumsuz temsillerin nedeni savaş, açlık/yoksulluk, salgın hastalık gibi acı verici koşullarla ilişkili olup, bu gerçeklik, ödüllü fotoğraflarla da kayıt altına alınmıştır. Olumlu ve olumsuz tutum aralığının Avrupa ve Kuzey Amerika'ya dair fotoğraflar söz konusu olduğunda daraldığı görülmektedir. Şöyle ki, Kuzey Amerika' da karelenen toplam 69 fotoğrafın 40 (\%57, 97)'ının olumsuz, 14 (\%20,29) 'ünün olumlu, 15 (\%21, 74)'inin ise nötr tutuma sahip olduğu tespit edilmiştir. Benzer durumun Avrupa kıtası için de geçerli olduğu görülmektedir. Avrupa'ya dair 123 fotoğraftan $65(\% 52,85)$ 'i olumsuz tutum içerirken, $40(\% 32,52)$ ' 1 olumlu, 18 (\%14,63)'i ise nötr şeklinde kodlanmıştır. Bu veriler, olumsuz tutumun dezavantajlı bölgelerde kayda geçirilmesinin daha değerli olduğu şeklindeki alan pratiğinin/habitusunun bir sonucu olarak okunmalıdır.

Tablo 4. Tutumun kıtalar özelinde dă̆ılımı

\begin{tabular}{lllll}
\hline & $\mathbf{N}$ & $\mathbf{\%}$ & $\mathbf{\%}$ & $\mathbf{\%}$ \\
\hline Kita & Toplam & Olumsuz & Olumlu & Nötr \\
\hline Afrika & 77 & 92,21 & 7,79 & 0 \\
\hline Asya & 235 & 81,70 & 8,09 & 10,21 \\
\hline Orta Amerika & 31 & 80,65 & 16,13 & 3,23 \\
\hline
\end{tabular}




\begin{tabular}{lllll}
\hline Güney Amerika & 19 & 78,95 & 5,26 & 15,79 \\
\hline Kuzey Amerika & 69 & 57,97 & 20,29 & 21,74 \\
\hline Avrupa & 123 & 52,85 & 32,52 & 14,63 \\
\hline Avustralya & 4 & 75,00 & 25,00 & 0 \\
\hline
\end{tabular}

\section{Şiddet Vurgusu}

Çalışmada fotoğrafların şiddet içerip içermediği analiz edilen diğer bir olgudur. Şiddet var-yok şeklinde yapılan kodlama sonucunda 574 fotoğraftan 341 (\%59,41)'nin şiddet imgeleri içerdiği, 233 (\%40,59)'ünün ise içermediği sonucuna varılmıştır. Neil Postman (2006) televizyonda şiddetin sattı̆ını, cinsellik ile birleşen şiddetin ise daha çok sattığını yazmıştır. Çalışmamız, bu ifadeyle tutarlı bir sonuca ulaşmıştır. Ödüllü fotoğraflardan 341'inin şiddet içermesi, uluslararası basın fotoğrafçılı̆̆ alanında şiddetin de alan pratiğine dönüştüğünün bir göstergesidir.

Şiddetin kıtalara göre dağılımında ise Tablo 5'ten de anlaşılacağ başta Ortadoğu olmak üzere bitmeyen savaşların yaşandığı Asya kıtası $\% 47,80$ ile (163 fotoğraf) başı çekerken, iç karışıklık, mültecilik, açlık/yoksulluk ve salgın hastalıkların merkezi olarak bilinen Afrika'nın ise \%18,77 şiddet içerikli fotoğrafla ikinci sırada yer aldığı görülmektedir. Üçüncü sırada ise \%14,96'lık oranla Avrupa yer almaktadır.

Tablo 5. Şiddetin kıtalara göre dağılımı

\begin{tabular}{lll}
\hline Kuta & $\mathbf{N}$ & $\%$ \\
\hline Asya & 163 & 47,80 \\
\hline Afrika & 64 & 18,77 \\
\hline Avrupa & 51 & 14,96 \\
\hline Kuzey Amerika & 29 & 8,50 \\
\hline Orta Amerika & 19 & 5,57 \\
\hline Güney Amerika & 10 & 2,93 \\
\hline Avustralya & 2 & 0,59 \\
\hline Bilinmeyen & 3 & 0,88 \\
\hline
\end{tabular}

Şiddet içerikli fotoğraflar kıtalar özelinde değerlendirildiğinde çalışma kapsamında incelenen ve Asya'da karelenen 235 fotoğrafın 163'ünün şiddet imgesi taşıdığı dikkat çekmektedir. Tablo 6 incelendiğinde bu oran Afrika'da daha çarpıcı bir boyuta ulaşmaktadır. Çünkü Afrika'da karelenen 77 fotoğrafın 64 'ünde şiddet imgesi mevcuttur. Avrupa' da çekilen 123 fotoğraftan 51'inde, Kuzey Amerika'da karelenen 69 fotoğrafın ise 29'unda şiddet imgesi bulunmaktadır. Şiddet içeriğinin kıtalara göre dağılımında Kuzey Amerika ve Avrupa söz konusu olduğunda durum tersine dönmektedir. 
Zira Kuzey Amerika'da karelenen şiddet içerikli fotoğrafların oranı \%42,03, Avrupa'da ise \%41,46 şeklinde saptanmış olup şiddet ögesi içermeyen fotoğrafların oran olarak içerenlerden fazla olduğu sonucuna ulaşılmıştır. Bu durum her iki kıtanın da dünyanın geri kalan bölgelerinin gerçeği olan terör, savaş, mültecilik, açlık, yoksulluk gibi makro ölçekli sorunlardan görece azade oluşu ile açıklanabilir. Bu da gösteriyor ki uluslararası basın fotoğrafçllığı alanının habitusu, şiddet ve olumsuzluğu ağırlıklı olarak Asya, Afrika, Orta ve Güney Amerika'da kareleme eğilimindedir.

Tablo 6. Şiddetin Kıtalar Özelinde Dağılımı

\begin{tabular}{llll}
\hline Kita & N (Toplam) & Evet (\%) & Hayır (\%) \\
\hline Afrika & 77 & 83,12 & 16,88 \\
\hline Asya & 235 & 69,36 & 30,64 \\
\hline Orta Amerika & 31 & 61,29 & 38,71 \\
\hline Güney Amerika & 19 & 52,63 & 47,37 \\
\hline Kuzey Amerika & 69 & 42,03 & 57,97 \\
\hline Avrupa & 123 & 41,46 & 58,54 \\
\hline Avustralya & 4 & 50,00 & 50,00 \\
\hline
\end{tabular}

\section{Konular ve Coğrafyalar}

Çalışmada üzerinde durulan diğer bir nokta ise ödüllü fotoğrafların ağırlıklı olarak odaklandığı konulardır. Buna ilişkin yapılan analiz sonucunda fotoğraflar, Tablo 7'de görüleceği üzere 14 kategori belirlenerek kodlanmıştır. Çalışmanın bu bölümünde çoklu kodlama tekniği kullanılmış ve bir fotoğraf birden fazla kategoriye kodlanabilmiştir. Oluşturulan kategorilerden hiçbirisine kodlanamayan fotoğraf sayısı (Diğer) 18 olarak tespit edilmiştir. Analize tabi tutulan 574 fotoğraftan 556's1 14 kategoriye çoklu kodlama yöntemiyle $840 \mathrm{kez}$ kodlanmıştır. Fakat yüzde hesaplamaları toplam fotoğraf sayısı olan 574 üzerinden her bir kategori için ayrı ayrı hesaplanmıştır (Örneğin savaş/sivil savaş/iç karışıklık kategorisi için 162x100/574=28,22; açlık/yoksulluk kategorisi için 124x100/574=14,76 gibi). Hesaplamalar sonucunda her bir konunun bir kıta içerisindeki oranını gösteren Tablo 8'e; her bir konunun kıtalara göre dağılımını gösteren Tablo 16'ya (Ek 1) ulaşılmıştır. Bu başlık altındaki oranlar Tablo 7, Tablo 8 ve Ek 1/Tablo 16 doğrultusunda yorumlanmıştır. 
Tablo 7. Fotoğraflarnn Konuları

\begin{tabular}{llllll}
\hline Fotoğrafların Konusu & $\mathbf{N}$ & $\mathbf{\%}$ & Fotoğrafların Konusu & $\mathbf{N}$ & $\mathbf{\%}$ \\
\hline Savaş/Sivil Savaş/İç Karışıklık & 162 & 28,22 & Ötekileştirme/Ayrımclık & 30 & 5,23 \\
\hline Açlı/Yoksulluk & 124 & 21,60 & Terör & 27 & 4,70 \\
\hline Gündelik Hayat & 81 & 14,11 & Doğal Afetler & 23 & 4,01 \\
\hline Siyasi Aktörler & 78 & 13,59 & Kazalar & 23 & 4,01 \\
\hline Tören & 67 & 11,67 & Spor & 21 & 3,66 \\
\hline Göç/Mültecilik & 62 & 10,80 & Doğa/Çevre & 21 & 3,66 \\
\hline Hastalık/Engellilik & 60 & 10,45 & Diğer & 18 & 3,14 \\
\hline Toplumsal Hareketler & 43 & 7,49 & & & \\
\hline
\end{tabular}

Tablo 8. Kıtalara Göre Konuların Dağılımı

\begin{tabular}{lllllll}
\hline & Afrika & Asya & $\begin{array}{l}\text { Kuzey } \\
\text { Amerika }\end{array}$ & $\begin{array}{l}\text { Güney } \\
\text { Amerika }\end{array}$ & $\begin{array}{l}\text { Orta } \\
\text { Amerika }\end{array}$ & Avrupa \\
\hline Doğal Afetler & 1,30 & 5,96 & 1,45 & 5,26 & 9,68 & 1,63 \\
\hline Kazalar & 2,60 & 3,40 & 1,45 & 5,26 & 0,00 & 8,94 \\
\hline Savaş/Sivil Savaş/ İç Karışılık & 36,36 & 45,11 & 0,00 & 21,05 & 12,90 & 15,45 \\
\hline Terör & 3,90 & 2,55 & 11,59 & 5,26 & 16,13 & 3,25 \\
\hline Toplumsal Hareketler & 2,60 & 9,36 & 7,25 & 15,79 & 9,68 & 6,50 \\
\hline Mültecilik/Göç & 27,27 & 11,06 & 1,45 & 5,26 & 6,45 & 8,94 \\
\hline Hastalık/Engellilik & 24,68 & 7,66 & 17,39 & 5,26 & 0,00 & 7,32 \\
\hline Ötekileştirme/Ayrımcılık & 9,09 & 3,83 & 10,14 & 0,00 & 9,68 & 2,44 \\
\hline Açlık/Yoksulluk & 57,14 & 20,43 & 7,25 & 21,05 & 29,03 & 9,76 \\
\hline Gündelik Hayat & 6,49 & 11,91 & 18,84 & 10,53 & 19,35 & 16,26 \\
\hline Tören & 2,60 & 11,49 & 7,25 & 0,00 & 12,90 & 21,14 \\
\hline Spor & 3,90 & 1,70 & 2,90 & 0,00 & 0,00 & 8,13 \\
\hline Siyasi Aktörler & 2,60 & 10,21 & 30,43 & 15,79 & 22,58 & 16,26 \\
\hline Doğa/Çevre & 5,19 & 3,83 & 2,90 & 5,26 & 0,00 & 2,44 \\
\hline Diğer & 3,90 & 1,70 & 5,80 & 10,53 & 0,00 & 1,63 \\
\hline
\end{tabular}

\section{Savaşın Coğrafyası Asya}

Tablo 7'den anlaşılacağı üzere fotoğrafların konularına göre genel dağılımında 162 fotoğrafla savaş/sivil savaş ve iç karışıklıklar en yüksek orana sahiptir. 162 savaş fotoğrafının 106'sının bu kıtada karelenmiş olması Asya kıtasının savaş gerçeğinin altını çizmektedir. Asya'da karelenen 235 ödüllü fotoğrafın içerisindeki savaş fotoğraflarının oranı \%45,11 (Tablo 8) iken bu rakam toplamı 162 olan savaş fotoğrafı üzerinden değerlendirildiğinde \%65,43'lük bir oranla karşılaşılmaktadır. Afrika'da ise toplam 77 ödüllü fotoğrafın 28 'i $(\% 36,36)$ savaş fotoğrafı kategorisine dâhildir. Savaş fotoğrafları içerisinde Afrika'nın payına bakıldığında bu oranın \%17,28 olduğu görülmüştür. Avrupa kıtasında karelenen ödüllü 123 fotoğraftan $19^{\prime} \mathrm{u}(\% 15,45)$ savaş fotoğrafıdır ve Avrupa savaş fotoğrafları sıralamasında \%11,73'lük oranla üçüncü sırada bulunmaktadır. Kuzey Amerika'ya dair fotoğrafların hiçbiri bu kategoride yer almamaktadır. Ayrıca çalışma kapsamına alınan 
fotoğraflar arasında Avustralya'da karelenen sadece 4 fotoğraf bulunduğundan, bu coğrafyaya dair anlamlı bulgulara ulaşılamamış olup, bu kıtaya ilişkin verilere Tablo 8' de yer verilmemiştir.

Dünyanın çeşitli coğrafyalarında karelenen ve ödül alan savaş fotoğrafları incelendiğinde (Görsel 1), fotoğraf anlatılarının birtakım benzer imgeler üzerinden kurulduğu görülmektedir. Savaş anlatılarında şiddet öğelerinin bulunduğu fotoğraflar erkeklerle ilişkilendirilirken savaşın mağdurları olarak kadın ve çocuklar gösterilmiştir. Kadın ve çocuklar ya kamplarda ya da hastanelerde belgelenirken bu fotoğraflarda çoğu kez kadın üzerinden gözyaşı, ölüm, cenaze töreni, mezarlık, yas, matem vb. temsiller öne çıkmaktadır. 162 savaş fotoğrafının 116'sında erkek, 70'inde çocuk, 65'inde ise kadın imgesi yer almaktadır. Savaş erkeklik alanı ile ilişkili görülen bir olgudur ve savaşın eyleyenleri erkeklerdir. Savaş fotoğraflarındaki suç aleti temsili açısından bakıldığında 40 fotoğrafta suç aletinin olduğu ve bunların 38'inin erkek, 2'sinin ise çocuk tarafından kullanıldığı tespit edilmiştir. Özetlemek gerekirse savaşı başlatan ve yürüten erkek egemenler olmasına rağmen savaşın sonuçlarına katlananları ve mağdur olanları medya kadın ve çocuklar olarak göstermiştir. Bu anlatılar, liberal medyanın haber anlatısıyla uyumludur (Snoubar\&Duman, 2016; Nagel, 1998). Bu, uluslararası basin fotoğrafçılığı alanın da takip ettiği bir kritere dönüşmüş durumdadır. Veriler foto muhabirlerinin habitusunun, olayı kadın ve çocuk üzerinden anlatmaya meyilli olduğunu düşündürtmektedir.

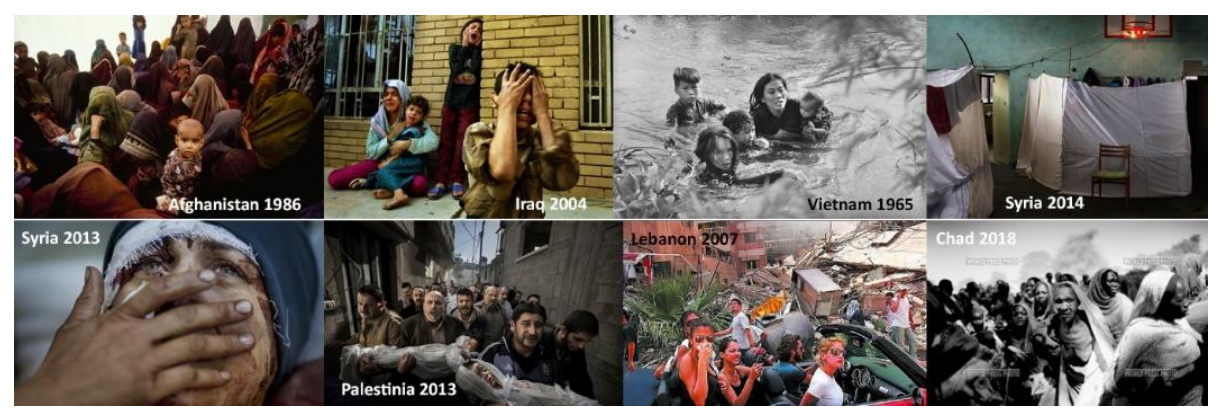

Görsel 1. 1956'dan 2013'e Dünyadaki Bazı Savaşlar

\section{Açlık ve Yoksulluğun Coğrafyası Afrika}

Ödüllü fotoğrafların belgelediği açlık/yoksulluk sorununa dair ilk akla gelen kıta Afrika olmakla birlikte genel toplamda Afrika kıtasında çekilen 
fotoğrafların sayıca az olması nedeniyle bu kategoride de siralamada Asya öne çıkmıştır. Başka bir ifadeyle açlık/yoksulluk kategorisindeki 124 fotoğrafın 48'i Asya'da, 44'ü Afrika'da, 12'si ise Avrupa'da çekilmiştir. Halbuki Afrika'ya dair 77 fotoğrafın 44'ü yani \%57'si açlık/yoksulluk temsili barındırmaktadır. Çalışma kapsamında yer alan Afrika'da karelenmiş ödüllü fotoğraflar kategorik olarak değerlendirildiğinde yoksulluğu savaş, hastalık ve mültecilik kategorilerinin izlediği görülmektedir.

Açlık/yoksulluk kategorisine yerleştirilen fotoğraflarda yoksulluk anlatıSı fotoğrafta yer alan aktörler, objeler ve mekân imgesi üzerinden kurulmuştur. Bununla birlikte bu fotoğraflarda kadın ve çocuk temsillerinin öne çıtığı görülmektedir. Yoksulluk ve olumsuz yaşam koşulları nedeniyle hasta, bitkin, kemikleri sayılan, çoğunluğu Afrikalı çocuklar sıklıkla annelerinin kucağında ya da anneleri, ölmek üzere olan çocuklarının başucunda çaresizce gözyaşı dökerken betimlenmiştir. Toplumsal cinsiyetçi tavrın liberal habercilik anlayışı ile uyumu bu fotoğraflarda da belirgindir (Galtung\&Ruge, 1965; Gencel Bek, 2010; İnal, 1996; Çelenk, 2010). Şöyle ki, kad1nın toplumsal rollerini annelik alanı üzerinden kuran ataerkil bakış açısı çocuğun beslenmesi, sağliklı biçimde yetiştirilmesi, hasta olduğunda bakımının sağlanması gibi görevleri annelere yüklemektedir (Yıldız \& Ördem, 2018; Sancar, 2014; Altınay, 2013; Butler, 1999). Bu bakış açısını yeniden üreten medyanın, haber profesyonelleri açlı/yoksulluk gibi acı verici bir konuda, sorunun hiç de nedeni olmayan kadın ve çocuk imgelerini kullanmayı habitusları gereği tercih etmekte, bir kadının çocuğuna karşı hassasiyetini, kaybetme korkusunu, çocuğu aç kaldığında hissettiği çaresizliği alımlayıcılar üzerinde özdeşleşme ve dramatik etki yaratmak amacıyla kullanmaktadır (Östgaard, 1965; Kepllinger, 1989; Shoemaker, 1991). Afrika'ya dair yoksulluk gerçeği, ödüllü fotoğraflar aracılığıyla yeniden inşa edilmekte ve dolaşıma sokularak bu yöndeki düşünce pekiştirilmektedir. 

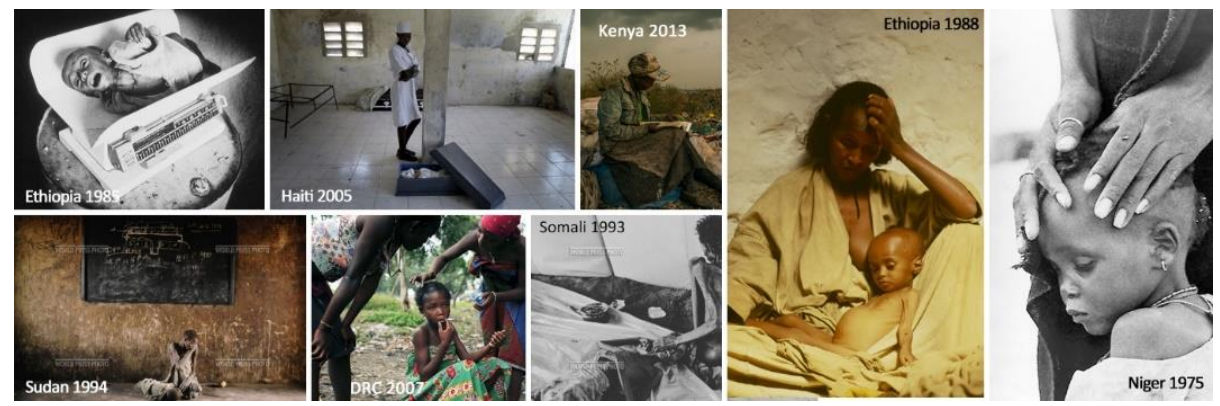

Görsel 2. Afrika'da açlik ve yoksulluk

\section{Avrupa'nın ve Kuzey Amerika'nın Gündelik Yaşamı}

Gündelik hayat kategorisi toplumsal koşullar çerçevesinde gerçekleşen yaşam koşullarını ve aynı zaman ve mekânları paylaşan insanların rutin pratiklerini ifade etmektedir. Bu kapsamda Gündelik Hayat kategorisine 81 kodlama yapılmıştır. Çalışma kapsamında incelenen fotoğraflar içinde bu kategori savaş ve yoksulluktan sonra üçüncü sırada yer almaktadır. Bu fotoğrafların 28'i Asya'da, 20'si Avrupa'da, 13'ü ise Kuzey Amerika'da çekilmiştir. Asya'da karelenen ödüllü fotoğrafların toplam sayısının 235 olduğu düşünüldüğünde bu kıtadan gündelik hayat temsillerinin aslında ağırlıkta olmadığ1 görülecektir ki bu oran \%11,91 olarak saptanmıştır. Kuzey Amerika'nın temsil edildiği 69 fotoğraftan \%18,84'ü, Avrupa'nın temsil edildiği 123 fotoğrafın ise $\% 16,26$ 'sında gündelik hayat kategorisine kodlanmıştır.

Fotoğraflarda gündelik hayatı temsil eden imgeler (Görsel-3), genel olarak iş yaşamı, sokaktaki insanlar, eğitim kurumları ve eğitim süreçleri, alışveriş mekânları, parklar, sanatsal etkinlikler vb. olgular üzerinden kurulmuştur. Bu fotoğrafların aktörlerinin dağılımına bakıldığında 39'unun kadın 52'sinin erkek, 34'ünün çocuk 2'sinin ise LGBTI bireylerden oluştuğu görülmektedir. 81 fotoğrafın 36'sı olumlu, 33'ü nötr, 20'si ise olumsuz tutum içermektedir. 


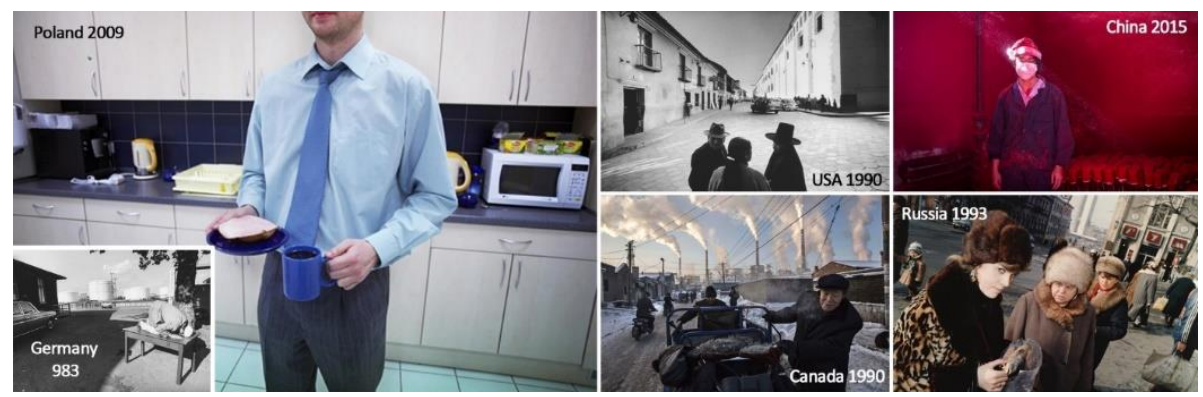

Görsel 3. Gündelik Hayat

\section{Siyasi Aktörlerin Coğrafyası Kuzey Amerika}

İncelenen fotoğraflar, siyaset alanının medyaya büyük ölçüde içerik sağlayan temel mekanizmalardan birisi olduğunu göstermiştir. Şöyle ki, çalışma kapsamında incelenen fotoğraflardan 78'i Siyasi Aktörler kategorisine kodlanmıştır. Bunların 24'ü (\%30,77) Asya, 21'i (\% 26,92) Kuzey Amerika, 20'si $(\%$ 25,64) ise Avrupa'da karelenen fotoğraflardır. Duruma kıtalar özelinde bakıldığında Kuzey Amerika'da \%30,43'lük payla politik aktörlerin en fazla temsil edilen kategori olduğu dikkat çekmektedir. Başka bir anlatımla Kuzey Amerika'da karelenen 69 ödüllü fotoğrafın 21'i siyasi aktör kategorisine kodlanmıştır. Bu fotoğrafların sadece 5'i olumsuz içeriklidir. Geriye kalan 16 fotoğraf ya olumlu ya da nötr imgelidir. Bu kategorideki fotoğraflarda aktörlerin temsil durumuna bakıldığında toplam 78 siyasi aktör içerikli fotoğrafta 71 erkek, 21 kadın ve 7 de çocuk imgesinin yer aldığı görülmektedir. Siyasette erkek egemenliğini fotografik temsiller de gözler önüne sermektedir.

Siyasi aktör içerikli fotoğraflar incelendiğinde Kuzey Amerika'da karelenen ödüllü fotoğrafların, 1961 yılından 2001 yılına dek görev alan tüm ABD Başkanlarını temsil ettiği saptanmıştır. Fotoğraflar ABD'nin hem ulusal hem de uluslararası alandaki gücünü gösteren, pekiştiren ve diğer ülkeler için de örnek teşkil eden imgeler içermektedir. Örneğin ABD'li foto muhabiri Barbara Kinney tarafindan karelenen ve 1996 yılında People in the News kategorisinde birincilik ödülü alan Görsel-4 ${ }^{1}$ incelendiğinde Başkan Clinton

\footnotetext{
${ }^{1}$ Filistin lideri Arafat, İsrail Başbakanı Rabin, Mısır Devlet Başkanı Mübarek ve Ürdün Kralı Hüseyin Filistin'in Batı Şeria'daki özerkliğini genişletmek üzere yapılan imza töreni öncesinde Clinton'un kravatını bağlamasını izleyerek kravatlarını onun gibi bağlamaya çalışmaktadırlar (WPP, People in the News, Birincilik Ödülü, Singles, 1996) .
} 
kravatını bağlarken Doğulu liderlerin Clinton'ı taklit ederek kravatlarını bağlamaya çalıştıkları görülmektedir. Başka bir anlatımla Batı ve modernlik olgusuyla ilişkilendirilen bir simge olan kravatın nasıl bağlanacağı Doğululara/anti-modern olarak nitelendirilen toplumların liderlerine öğretilmektedir. Ayrıca Batının siyaset/siyasi aktör olarak da güçlü olduğunu anlatan fotoğrafların oranının fazla olduğunu belirtmekte fayda vardır.

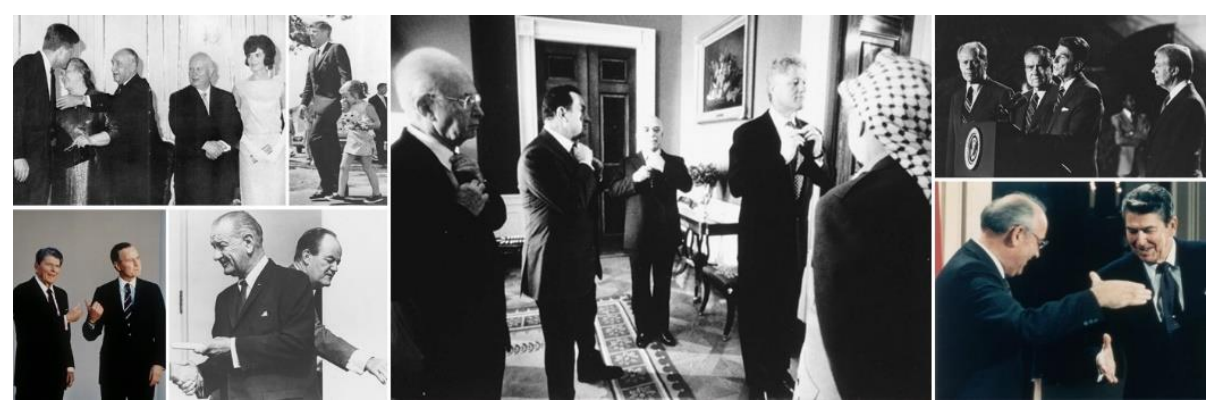

Görsel 4. Siyasi Aktörler

\section{Olumsuzluk İçeren Törenler}

Tören kategorisinde yer alan toplam 67 fotoğrafın, 27'si (\% 40,30) Asya, 26's1 $(\%$ 38, 81) Avrupa, 5’i (\% 7,46) ise Kuzey Amerika'da karelenmiştir. Tören imgesi içeren fotoğraflar Tablo $\mathbf{8}^{\prime}$ den anlaşılacağı üzere kıtalar özelinde değerlendirildiğinde ise Avrupa kıtasına dair fotoğraflar arasında tören kategorisine dâhil fotoğrafların en yüksek paya sahip olduğu sonucuna ulaşılmıştır. Şöyle ki Avrupa'da karelenen 123 ödüllü fotoğrafın 26's1 yani $\% 21,14$ 'ü bu kategoriye ilişkindir. Tören fotoğraflarında 23 olumlu, 35 olumsuz ve 9 nötr tutum içeriğine rastlanmıştır. Fotoğrafların aktörlerine göz atıldığında 55 erkek, 41 kadın, 17 çocuk ve 1 LGBTI birey temsili saptanmıştır. Bu fotoğraflar (Görsel 5) genel olarak değerlendirildiğinde dügü̈n, cenaze, anma, dini etkinlikler, spor etkinlikleri, askeri törenler, yıldönümleri vb. içeriklerden oluşmaktadır. Bu kategoriye kodlanan fotoğrafların genel tutumu da yine olumsuz yöndedir. Foto muhabirlerinin gündelik yaşamın sıkıntılı ya da hüzünlü yönlerini kayıt altına alma eğilimi gösterdiği söylenebilir. Yine bu durum da foto muhabirliği alanının, alan pratiği olarak okunabilir. 

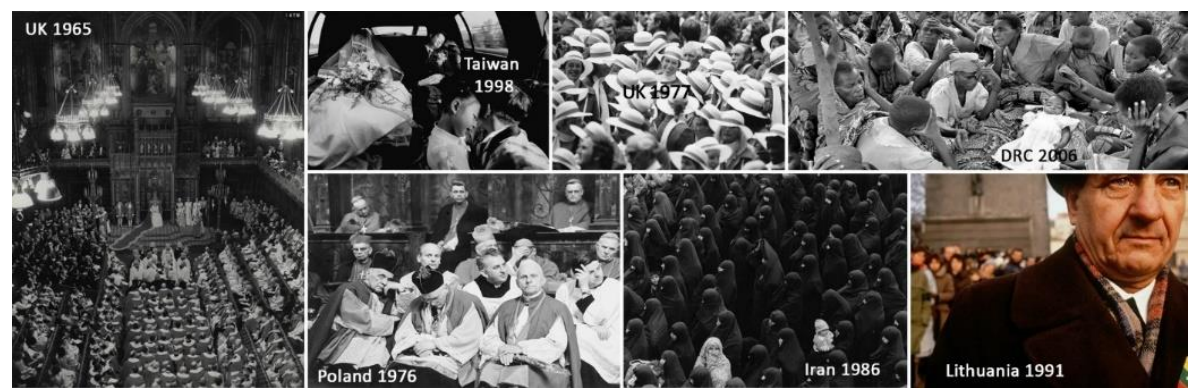

Görsel 5. Dünyadaki bazı törenler

\section{Göç ve Mülteciliğin Coğrafyası Asya ve Afrika}

Dünyada sonu gelmeyen savaş ve iç karışıklıklar mülteci sorununa da yol açarken, uluslararası bir problem olarak algılanan bu konunun WPP çerçevesinde çekilen ödüllü fotoğraflar aracılığılla tespitinde Asya ve Afrika kıtaları öne çıkmıştır. Bu kategoriye kodlanan toplam 62 fotoğrafın 26 'sının Asya, 21'inin ise Afrika'da karelendiği saptanmıştır. Göçmenlerin/mültecilerin/sığınmacıların çoğu kez Türkiye'yi köprü olarak kullanarak ulaşmaya çalıştıkları Avrupa ise bu kategoride 11 fotoğrafla 3. sırada yer almıştır. Afrika kıtasının açlık yoksulluk, savaş/ iç karışıklık, salgın hastalıklar gibi koşulları bu coğrafya insanlarını uzak bölgelere yerleşmeye zorlarken, Afrika'da karelenen fotoğrafların kendi içinde dağılımında bu realite oransal olarak da doğrulanmaktadır. Şöyle ki, Afrika'ya dair fotoğrafların $\% 27,27$ 'sinde mültecilik konusunun işlendiği saptanmıştır. Tablo $\mathbf{8}^{\prime}$ den de anlaşılacağı üzerinde kategorilerin kıtalara göre dağılımında mültecilik konusunun en fazla temsil edildiği kıta Afrika olmuştur.

Mültecilik konusuna dair fotoğraflar incelendiğinde (Görsel 6), öne ç1kan imgelerin mülteci kamplarındaki olumsuz yaşam koşulları, beslenme, hijyen, barınmaya dair sorunlar, salgın hastalıklar ve ölüme meydan okuyan umut yolculuklarına dair olduğu görülmektedir. Dünyada mültecilik konusunun adeta simgesi haline gelen ve umuda yolculuk diye adlandırılan, kaçak yollardan bir ülkeye ulaşma isteği, bir botun kapasitesinin çok üzerindeki sayıda insanın tehlikeli yolculuğunu ifade etmektedir. Çalışma kapsamında göç/mültecilik kategorisine kodlanan ödüllü fotoğraflarda umut yolculuğuna dair imgeler ağırlıktadır. Ayrıca savaş ve yoksulluk kategorilerinde olduğu gibi bu kategoride de kadın ve çocuk temsilleri çoğunluktadır. 


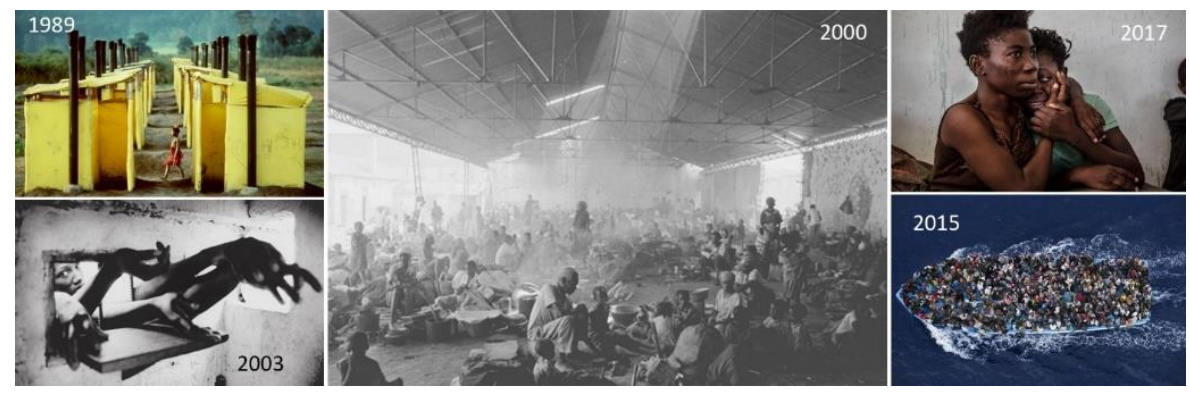

Görsel 6. Kamplardaki mülteciler ve umut yolculuğu

Ana Akım Medyanın Başlıca Haber Konularndan Biri: Hastalık/Engellilik

Hastalık/engellilik kategorisinde toplam 60 fotoğraf kodlanmıştır. Bu fotoğrafların 19'u (\%31,67) Afrika'da, 18'i (\%30,00) Asya'da 12'si $(\% 20,00)$ ise Kuzey Amerika'da karelenmiştir. Fotoğraflarda, aktörlerin temsili açısından 34 kadın, 28 erkek, 32 çocuk, 2 de LGBTI birey temsiline ulaşılmıştır. Fotoğrafların 55'i olumsuz, 3'ü olumlu, 2'si ise nötr tutuma sahiptir. Hastalık ve engellilik kategorisinde kıtalar özelinde inceleme yapıldığında \%24,68'lik payla Afrika'da çekilen fotoğraflarda diğer coğrafyalarla kıyaslandığında yüksek oranda temsil edildiği saptanmıştır. Afrika'da oranın bu şekilde çıkıyor olması bölgedeki açlık/yoksulluk, savaştan kaynaklı mültecilik gibi olumsuz yaşam koşullarının doğurduğu kolera, dizanteri, hepatit gibi bulaşıcı ve salgın hastalıklarla açıklanabilir. Bunanla birlikte yaşam standartlarının yüksek olduğu Kuzey Amerika'da \%17,39 oranında Hastalık/Engellilik kategorisinde fotoğraf (Görsel 7) bulunmaktadır. AIDS hastalığına dair temsiller bu oranda etkili olmuştur.

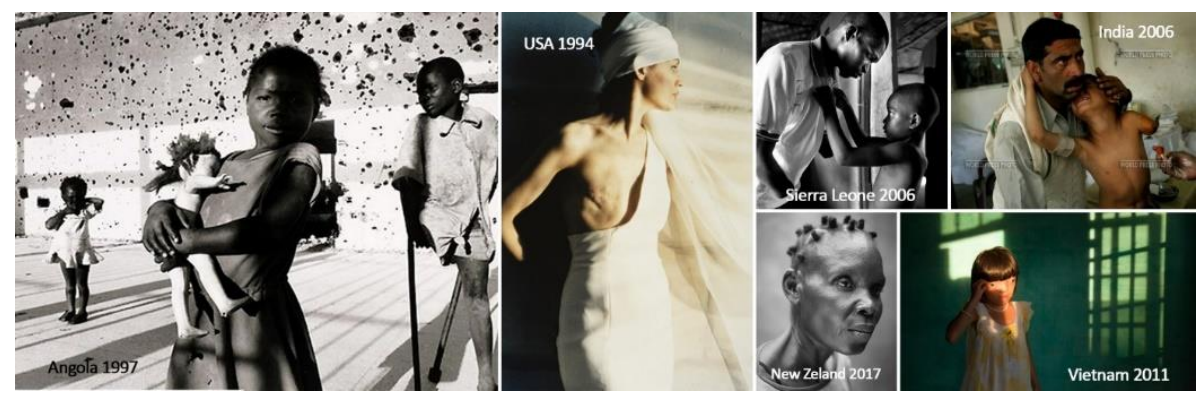

Görsel 7. Dünyada hastalık/engellilik temsili 


\section{Toplumsal Hareketlerde Kadına Yönelik Şiddet}

Çalışmada ele alınan fotoğraflardan $43^{\prime}$ ü bu kategoriye kodlanmıştır. Bunlarin 22'si (\% 51,16) Asya, 8'i (\% 18,60) Avrupa, 5'i (\%11,63) Kuzey Amerika'da karelenmiştir. Fotoğrafların kıtalar özelinde dağılımında Güney Amerika öne çıkmaktadır. Güney Amerika'da Toplumsal Hareketler bağlamındaki fotoğrafların oranı \%15,79 olarak belirlenmiştir. Bu kategorideki 43 fotoğrafın 41'İ olumsuz iken yalnızca 3'ü nötr tutuma sahiptir. Kategoriye aktörler açısından bakıldığında ise 30 erkek,16 kadın, 6 çocuk ve 1 LGBTI birey temsiline ulaşılmıştır. 43 fotoğraftan 41 'inin şiddet içerdiği saptanmıştır. Bu fotoğrafların 18 'inde asker ve polis gibi güvenlik güçleri ilişkin imgelere rastlanmıştır. Bu fotoğrafların 14'ünde suç aleti bulunurken, suç aletlerinin kullanıcısının tüm fotoğraflarda erkekler olduğu görülmüştür. Ayrıca bu kategorideki fotoğrafların 15'inde ölü ve yaralı imgesi yer almaktadır. Nicel olarak bakıldığında bu kategorideki fotoğrafların (Görsel 8) aktörlerinin çoğunluğu erkek olmakla birlikte, kadına ilişkin imgelerde kadına yönelen erkek şiddetinin kadını mağdur ve kurban gösteren bir anlatıyla betimlendiği dikkat çekmektedir.

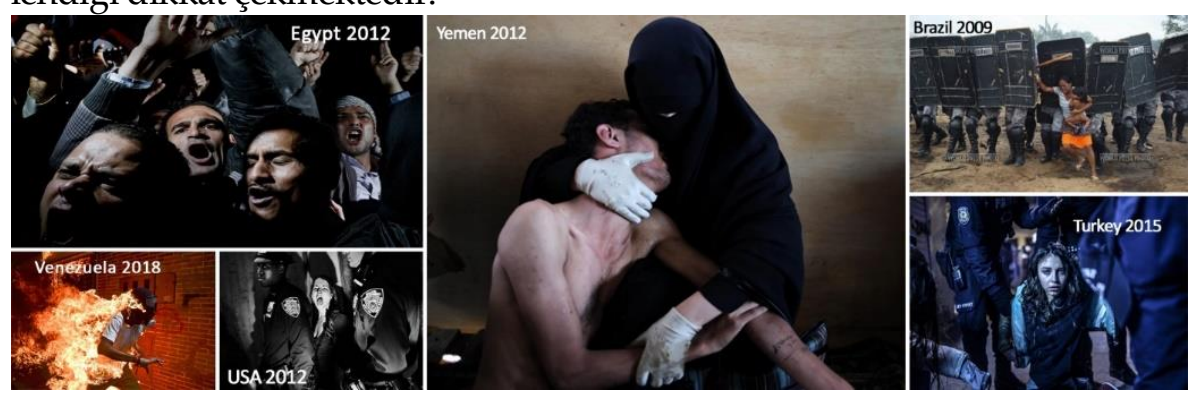

Görsel 8. Dïnyadaki Toplumsal Hareketlerin Temsili

\section{Toplumsal Cinsiyet, Etnisite ve Irk Temelli Ötekileştirme/Ayrımcılık}

Bu kategoriye kodlanan fotoğraf sayısı 30'dur. Bu fotoğrafların 9'u $(\% 30,00)$ Asya, 7'si (\% 23,33) Kuzey Amerika, 7'si (\% 23,33) Afrika kıtasında karelenmiştir. Kategori kıtalar özelinde incelendiğinde Ötekileştirme/Ayrımcılık kategorisinin Kuzey Amerika'da \%10,14 gibi yüksek bir paya sahip olduğu görülmektedir. Bu kategorideki 30 fotoğrafın 29'unun olumsuz tutuma sahip ve şiddet içerikli olduğu saptanmıştır. Fotoğraflarda (Görsel 9) yer alan aktörlere bakıldığında 20 erkek, 14 kadın, 10 çocuk ve 3 de LGBTI birey 
temsili olduğu görülmüştür. Fotoğraflarda yer alan ötekileştirme biçimlerinin; bireylerin cinsiyet yönelimleri ve ırk/renk ayrımcllı̆g gibi konular temelinde ağırlık kazandığı anlaşılmaktadır.

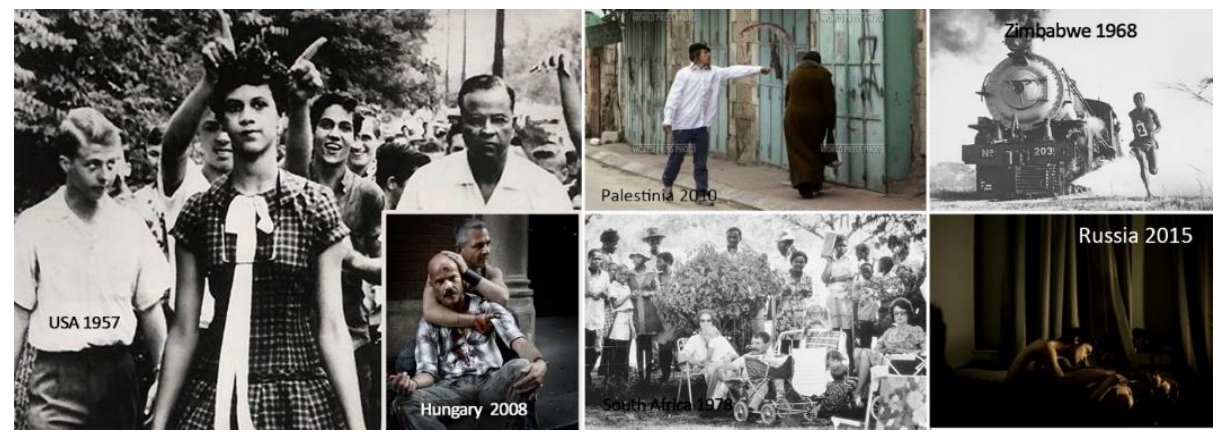

Görsel 9. Dünyada ötekileştirme/ayrımcılık temsili

Tablo 7 'den de anlaşılacağı üzere çalışma kapsamında yüzdelik değerleri 5 'in altında olan 6 kategori daha bulunmaktadır. Bu kategorilerden terör kategorisi 27 fotoğrafla $(\% 4,70)$ ilk sırada yer almıştır. Bu kategoride Kuzey Amerika en yüksek paya sahiptir. Kuzey Amerika'ya dair 69 fotoğraftan 9'u terör kategorisine yerleştirilirken, bunların arasında 9/11 Terör saldırısı ile ilgili fotoğrafların bulunuyor olması bu sonuca ulaşılmasında etkili olmuştur. Çalışma kapsamında Doğal Afetler kategorisine 23 fotoğraf $(\% 4,01)$, Kazalar kategorisine 23 fotoğraf $(\% 4,01)$, Spor kategorisine 21 fotoğraf $(\% 3,66)$, Doğa/Çevre kategorisine 21 fotoğraf $(\% 3,66)$ ve bu kategorilere dâhil olmadığı için Diğer kategorisine 18 fotoğraf $(\% 3,14)$ kodlanmıştır.

\section{Kâşifler: Foto Muhabirleri}

Foto muhabirleri, Bourdieu sosyolojisinde alanın habitusunu edinmiş ve bu habitusun yeniden üretilmesine katkı sunan (yarı-özerk) aktörlere denk düşmektedir. Ama bu çalışma foto muhabirlerini, ulaşılamayan bölgelere ulaşarak oralardaki olayları kendi bakış açılarıyla kayıt altına alarak dünyaya duyurmalarından dolayı keşifçiler olarak nitelendirmeyi uygun görmüştür. Çünkü tarihte kâşiflerin üstlendiği görevi, günümüz modern dünyasında medya profesyonelleri üstlenmiş durumdadır. Kitlelerin bilmediği coğrafyalara ilişkin enformasyon üreterek oralara ilişkin bir gerçeklik algısı yaratan medya profesyonellerinin inşa ettiği bu gerçeklik, dünyayı medya 
yoluyla algılayan ve anlamlandıran kitlelerin de hakikatine dönüşmektedir. Örneğin, Shaheen'a göre, televizyonun Araplar hakkında ürettiği 4 değişmez kalıp yargı: onların olağanüstü servete sahip oldukları, barbarlıkları ve yobazlıkları, seks sapkınlıkları ve terör eylemlerinden zevk almalarıdır (akt. Karim, 2003, s.110).

Said, Oryantalizm adlı çalışmasının giriş bölümünde Avrupa başta olmak üzere Batı'nın Asya ve Afrika gibi Doğu ve Müslüman coğrafyaları egzotik, romantik bulduklarını ve bu bölgeleri ve bu bölgelerin yaşanmışlıklarını adeta avladıkların ifade etmektedir (Said, 2003, s.1). Said (2003, s.6), Batılıların, Doğuluları, onların yaşam tarzlarına ilişkin çok da bir fikir sahibi olmadan betimleyerek sorunlu imgeler oluşturdukları kanısındadır. Oryantalizm stratejisi, Batı'nın kendini üstün görme durumunu yumuşatarak eski çağlardan bu yana devam etmiştir. Yani Batı, hissettirmeden, çıkarları doğrultusunda Doğu'yu korumaya çalışmıştır. Buradaki amaç Batı'nın, Doğu nimetlerinden bir türlü vazgeçmemesidir. Batılı, Doğu'nun birçok toprağında kendi arzuları peşinde koşarken herhangi bir direnişle karşılaşmamıştır. Batılı, 18. yüzyılda Doğu'yu tanımak için yola çımış, hegemonik gücüyle Doğu'ya dalmıştır. Akademik çalışmalar da Doğu'nun gerçeklerine uydurulmuştur. 18. Yüzyıl sonlarından itibaren Batı hegemonyasının etkisiyle Doğu, akademide çalışmaya uygun, müzelerde gösterilebilir, sömürge ofislerinde yeniden yapılandırılan, antropoloji, biyoloji, dil bilim, ırkçılık ve tarih alanlarında yapılan insan ve evren ile ilgili tezlerde kuram geliştirilebilecek karmaşık bir alan olarak görülmeye başlanmıştır (Said, 2003, s.9).

Çalışmanın ikinci aşamasını oluşturan fotoğrafçılara ilişkin bilgilere göz atıldığında Avrupa ve Kuzey Amerika'nın nicel olarak açık ara üstünlüğe sahip olduğu dikkat çekmektedir. Foto muhabirlerini ülkelerine ve kıtlarına göre dağıttığımızda Tablo 9 ve Tablo $10^{\prime}$ daki verilere ulaşılmaktadır. $\mathrm{Bu}$ veriler incelendiğinde toplam 574 fotoğrafın $165^{\prime}$ inin $A B D$ uyruklu fotoğrafçlarca çekilmiş olması ABD'nin dünyanın tüm bölgelerine yayılan varlığını ve uluslararası alandaki iktidarını göstermektedir. Foto muhabirleri uyruklarına göre sıralandığında 46 fotoğrafçı ile Almanya ikinci, 45 fotoğrafçı ile İngiltere üçüncü sırada yer almaktadır. Tablo 9 incelendiğinde ilk $10^{\prime}$ da sadece iki Asya ülkesinin yer aldığı görülmektedir. 
Tablo 9. Foto muhabirlerinin/ profesyonellerinin ülkelere göre dağılımı

\begin{tabular}{|c|c|c|c|c|c|c|c|c|c|c|c|}
\hline Ülke & $\mathbf{N}$ & $\%$ & Ülke & $\mathbf{N}$ & $\%$ & Ülke & $\mathbf{N}$ & $\%$ & Ülke & $\mathbf{N}$ & $\%$ \\
\hline $\mathrm{ABD}$ & 165 & 28,75 & Polonya & 8 & 1,39 & Somali & 3 & 0,52 & Kolombiya & 1 & 0,17 \\
\hline Almanya & 46 & 8,01 & $\begin{array}{l}\text { Çek } \\
\text { Cumhuriyeti }\end{array}$ & 7 & 1,22 & Suriye & 3 & 0,52 & Misır & 1 & 0,17 \\
\hline Birleşik Krallık & 45 & 7,84 & Brezilya & 6 & 1,05 & Cezayir & 2 & 0,35 & $\begin{array}{l}\text { El } \\
\text { Salvador }\end{array}$ & 1 & 0,17 \\
\hline Rusya & 32 & 5,57 & Macaristan & 6 & 1,05 & Belçika & 2 & 0,35 & Haiti & 1 & 0,17 \\
\hline Fransa & 28 & 4,88 & Hindistan & 6 & 1,05 & Şili & 2 & 0,35 & Letonya & 1 & 0,17 \\
\hline Italya & 27 & 4,70 & İran & 6 & 1,05 & Küba & 2 & 0,35 & Litvanya & 1 & 0,17 \\
\hline Hollanda & 19 & 3,31 & Arjantin & 5 & 0,87 & Yunanistan & 2 & 0,35 & Malta & 1 & 0,17 \\
\hline İsveç & 19 & 3,31 & Bangladeş & 5 & 0,87 & Peru & 2 & 0,35 & Yeni Zelanda & 1 & 0,17 \\
\hline Danimarka & 16 & 2,79 & İsrail & 5 & 0,87 & Portekiz & 2 & 0,35 & Pakistan & 1 & 0,17 \\
\hline Çin & 10 & 1,74 & Meksika & 5 & 0,87 & Tayvan & 2 & 0,35 & Filistin & 1 & 0,17 \\
\hline Japonya & 10 & 1,74 & Türkiye & 5 & 0,87 & Venezuela & 2 & 0,35 & Filipinler & 1 & 0,17 \\
\hline İspanya & 10 & 1,74 & Norveç & 4 & 0,70 & Ermenistan & 1 & 0,17 & Romanya & 1 & 0,17 \\
\hline Avustralya & 9 & 1,57 & İsviçre & 4 & 0,70 & Avusturya & 1 & 0,17 & SIrbistan & 1 & 0,17 \\
\hline Güney Kore & 9 & 1,57 & Finlandiya & 3 & 0,52 & $\begin{array}{l}\text { Bosna- } \\
\text { Hersek }\end{array}$ & 1 & 0,17 & Yugoslavya & 1 & 0,17 \\
\hline Kanada & 8 & 1,39 & İrlanda & 3 & 0,52 & Bulgaristan & 1 & 0,17 & Zimbabve & 1 & 0,17 \\
\hline
\end{tabular}

WPP'de ödül alan fotoğrafçıların kıtalara göre dağılımında (Tablo 10) Avrupa'nın $262(\% 45,64)$ fotoğrafçı ile başı çektiği, Kuzey Amerika'nın 173 $(\% 30,14)$ fotoğrafçıyla ikinci sırada yer aldığı görülmektedir.

Tablo 10. Foto muhabirlerinin/ profesyonellerinin kıtalara göre dağılımı

\begin{tabular}{lll}
\hline Kuta & $\mathbf{N}$ & $\mathbf{\%}$ \\
\hline Avrupa & 262 & 45,64 \\
\hline Kuzey Amerika & 173 & 30,14 \\
\hline Asya & 92 & 16,3 \\
\hline Güney Amerika & 18 & 3,14 \\
\hline Afrika & 10 & 1,74 \\
\hline Avustralya & 10 & 1.74 \\
\hline Orta Amerika & 9 & 1,57 \\
\hline
\end{tabular}

Farklı kıtalarda çekilen fotoğrafları kareleyen fotoğrafçıların uyruklarına göre dağılımı Tablo 11'de aktarılmıştır. Bu açıdan değerlendirildiğinde incelenen fotoğraflar içerisinde en yüksek paya Asya sahip olmasına rağmen bu coğrafyada çekilen toplam 235 fotoğrafın yalnızca \%34,89'luk kısmının Asyalı fotoğrafçılarca karelendiği görülmektedir. 77 fotoğrafın ödüllendirildiği Afrika'da, kendi coğrafyasının gerçeğini belgeleyen fotoğrafçıların oranı ise \%9,09 olarak saptanmıştır. Afrika'nın dezavantajlı bölgelerindeki olumsuzlukları belgeleyen Avrupalı kâşiflerin oranı \%51,95 olarak gerçekleşmiştir. Buna karşın Avrupa'da karelenen fotoğrafların \%90,91'i yine Avrupalı fotoğrafçılar tarafından çekilirken, Afrikalı fotoğrafçıların bu coğrafyada karelediği fotoğraf oranı ise yalnızca $\% 0,83$ olarak saptanmıştır. 
Bu çerçevede dünyanın dezavantajlı bölgelerindeki olumsuz imgelerin üreticisinin de Batı olduğunu söylemek yanlış bir tespit olmayacaktır. Bu tespiti güçlendirecek bir başka veri ise Kuzey Amerika'da çekilen ödüllü fotoğrafların, üreticilerinin de yine $A B D$ ve Avrupa uyruklu fotoğrafçılar oluşudur. Kuzey Amerika'ya dair 69 fotoğraf yarışmada ödül alırken bu fotoğrafların 58'i ABD, 11'i ise Avrupalı fotoğrafçlarca çekilmiştir. Farklı bir değerlendirmeyle Kuzey Amerika'da karelenen fotoğrafların \%85,51'ini ABD uyruklu \%16, 81'ini ise Avrupalı fotoğrafçlar çekmiştir. Avrupa'da da benzeri durum söz konusudur. Avrupa'da karelenen ödüllü fotoğrafların \%90,91'i Avrupalı, \%7,44'ü ise Amerikalı fotoğrafçllar tarafından karelenmiştir. Avustralya'da çekilen 4 fotoğrafın 4'ü de Avusturalyalı foto muhabirlerine aittir. Bu veriler, enformasyon üretimi açısından avantajı bölgelerin kendi enformasyon üretimini gerçekleştirmede yeterli; Asya, Afrika, Güney ve Orta Amerika gibi dezavantajlı bölgelerin ise yetersiz olduklarını göstermektedir. Bu bağlamda en yetersiz bölgenin Afrika olduğunu belirtmekte fayda vardır.

Tablo 11. Kitalarda çekilen fotoğraflarn kareleyen fotoğrafçıların uyruklarn

\begin{tabular}{llllllll}
\hline \multirow{2}{*}{$\begin{array}{l}\text { Fotoğrafların } \\
\text { Kitaları }\end{array}$} & $\begin{array}{l}\text { Kuzey } \\
\text { Amerika }\end{array}$ & Avrupa & Asya & Afrika & $\begin{array}{l}\text { Orta } \\
\text { Amerika }\end{array}$ & $\begin{array}{l}\text { Güney } \\
\text { Amerika }\end{array}$ & Avustralya \\
\hline Kuzey Amerika & 85,51 & 16,18 & 0 & 0 & 0 & 0 & 0 \\
\hline Avrupa & 7,44 & 90,91 & 0,83 & 0,83 & 0 & 0,83 & 0,83 \\
\hline Asya & 28,09 & 33,19 & 34,89 & 0,43 & 0,43 & 1,28 & 1,28 \\
\hline Afrika & 29,87 & 51,95 & 6,49 & 9,09 & 0 & 0 & 2,60 \\
\hline Orta Amerika & 29,03 & 32,26 & 6,45 & 0 & 25,81 & 6,45 & 0 \\
\hline Güney Amerika & 15,79 & 15,79 & 5,26 & 0 & 0 & 63,16 & 0 \\
\hline Avustralya & 0 & 0 & 0 & 0 & 0 & 0 & 100 \\
\hline
\end{tabular}

\section{Yayıncılar: Bilginin Batı Merkezli Dünyasallaştınlması}

Çalışmanın kuramsal kısmında değinildiği gibi, medya dünya genelindeki enformasyon döngüsünü sağlayan bir mekanizmadır. Dünya nüfusunun 8 milyara ulaştığı günümüz toplumlarında aracılanmamış iletişim biçimleri çok sınırlı düzeyde kalmaktadır. Özellikle kitle toplumu içerisinde insanları birbirlerinden haberdar eden, ilgi duyacaklarl, üzerinde düşünecekleri ya da görmezden gelecekleri konuları medya kuruluşları seçmekte, biçimlendirmekte ve dolaşıma sokmaktadır. Başka bir anlatımla, medya kuruluşları toplumsal sistemin ekonomik ve politik birer parçasıdır ve güç/iktidar ilişkileri çerçevesinde hareket eden bir endüstrinin üyeleridir. Bu iletişim ve kül- 
tür endüstrileri, insanların neyi göreceğine ve duyacağına, ne hakkında konuşacağına, bu endüstrilerin sahiplik ve mülkiyet yapısına göre şekillenen ve kiralı/ücretli profesyonellerin üretimleri doğrultusunda karar verir (Yaylagül, 2006, s.151-152).

Uluslararası medya organizasyonları gündemlerine alacakları konulara, bu konuların içeriklerine ve sunum biçimlerine bazı filtreleri dikkate alarak karar verirler. Bu çalışmada incelediğimiz fotoğrafların \%90,49'u ABD ve Avrupa merkezli medya kuruluşlarınca yayınlanmıştır (Tablo 12). Bu kuruluşların büyük bir kısmı ise medya holdinglerine bağlı ve uluslararası niteliktedir. Bu da gösteriyor ki dünyadaki enformasyon akışı Batı merkezli medya kuruluşları ve buna bağlı olarak da onların bakış açısıyla gerçekleşmektedir. Diğer bir ifadeyle başta Asya ve Afrika olmak üzere dünyaya dair algı Batı medyası aracılığıyla inşa edilmektedir. Çalışmamızın konu analizlerinde görüleceği üzere Batı tarafından oluşturulan Doğu algısı büyük oranda olumsuz içeriklidir. Said (2003, s.27), post modern dünyada televizyon, sinema ve tüm medya kaynaklarının, Doğu'ya ilişkin enformasyonu standart/klişe anlamlara sığdırarak biçimlendirdiğini, standartlaştırma ve kültürel sterotipleştirme yoluyla gizemli Doğu algısı yarattığını söylemektedir. Aşağıda betimlenen medyaya dair bulgular da bu saptamayla uyumludur.

Bu bölümde çalısmamıza dâhil ettiğimiz 574 fotoğrafın yayıncı kuruluş bilgileri analize tabi tutulmuştur. 574 fotoğrafın 509'unu kareleyen muhabirlerin hangi yayıncı kuruluşlarca yetkilendirildiğine göz atıldığında 528 yayıncı kuruluşa rastlanmıştır. Geriye kalan 65 fotoğrafı kareleyen fotoğrafçıların herhangi bir yayınc kuruluş tarafından yetkilendirilmediği sonucuna varılmıştır. Bu fotoğrafçların büyük bir çoğunluğunu Avrupalı freelancer olarak çalışan fotoğrafçılar oluşturmaktadır. Analizler sonucunda Tablo 12 ve Tablo 13 oluşturulmuştur. Bu tablolar incelendiğinde uluslararası alanda Doğu coğrafyasının enformasyonun merkezi olduğu, bu enformasyonu toplayıp dünyaya yayanın ise Batı medyası olduğu anlaşılmaktadır. Ödül alan fotoğrafçıları yetkilendiren 264 Kuzey Amerikalı $(\% 50,38)$ kuruluş ile 211 Avrupalı $(\% 40,11)$ medya kuruluşu sayısını topladığımızda 476 $(\% 90,49)$ rakamına ulaşılmaktadır (Tablo 12). Bu sayı Asya'da 42 $(\% 7,98)^{\prime}$ dir. Afrika'da ise bu fotoğrafları yayınlayan herhangi bir medya kuruluşuna rastlanmaması oldukça önemli bir bulgudur. 
Tablo 12. Ödüllü fotoğrafları yayımlayan medya kuruluşlarının kıtalara göre dağılımı

\begin{tabular}{lll}
\hline Kita & $\mathbf{N}$ & $\mathbf{\%}$ \\
\hline Kuzey Amerika & 265 & 50,38 \\
\hline Avrupa & 211 & 40,11 \\
\hline Asya & 42 & 7,98 \\
\hline Avustralya & 5 & 0,95 \\
\hline Güney Amerika & 4 & 0,76 \\
\hline Orta Amerika & 1 & 0,19 \\
\hline & 528 & 100,00 \\
\hline
\end{tabular}

Durum medya kuruluşları özelinde değerlendirildiğinde Batı merkezli, köklü ve uluslararası nitelikli haber ve fotoğraf ajanslarının öne çıktığı görülmüş̧ür. Bu incelemede ödüllü fotoğrafları yayınlayan ya da servis eden 205 yayıncı kuruluş tespit edilmiştir. ABD'nin köklü haber ajansı The Associated Press'in servis ettiği 49 fotoğraf ödül almıştır. Yine ABD kökenli Magnum Photos 23 fotoğrafla ikinci sırada yer alırken, onu ABD kökenli diğer bir medya kuruluşu olan Time 18 fotoğrafla izlemiştir. Reuters 15 (Birleşik Krallık), Getty Images 13 (ABD), Contact Press Images 12 (ABD), VII Agency 11 (ABD), Black Star 12 (ABD), United Press International 12 (ABD), Gamma 10 (Fransa), ITAR-TASS 10 (Rusya), Dagens Nyheter 9 (İsveç), The Washington Post 9 (ABD), Stern 8 (Almanya), The New York Times 8 (ABD), Agence France-Presse 7 (Fransa), Daily Mirror 7 (Birleşik Krallık), Agence Vu 6 (Fransa), Life 5 (ABD), RIA Novosti 6 (Rusya), Contrasto 5 (İtalya), Network Photographers 5 (Birleşik Krallık), Panos Pictures 5 (Birleşik Krallık), Politiken 5 (Danimarka), Sven Simon Fotoagentur 5 (Almanya) ve Sygma $5(A B D)$ fotoğraf ile öne çıkan yayıncı kuruluşlardır.

Tablo 13. Ödüllü fotoğrafları yayımlayan medya kuruluşlarını listesi

\begin{tabular}{lllllllll}
\hline Ülke & $\mathbf{N}$ & $\mathbf{\%}$ & Ülke & $\mathbf{N}$ & $\mathbf{\%}$ & Ülke & $\mathbf{N}$ & $\mathbf{\%}$ \\
\hline ABD & 264 & 50,19 & Finlandiya & 3 & 0,06 & Avusturya & 1 & 0,19 \\
\hline Birleşik Krallık & 56 & 10,65 & Japonya & 3 & 0,06 & Bulgaristan & 1 & 0,19 \\
\hline Almanya & 38 & 7,22 & İspanya & 3 & 0,06 & Kanada & 1 & 0,19 \\
\hline Fransa & 33 & 6,27 & Bangladeş & 2 & 0,04 & Kolombiya & 1 & 0,19 \\
\hline Rusya & 24 & 4,56 & Belçika & 2 & 0,04 & El Salvador & 1 & 0,19 \\
\hline Italya & 16 & 3,04 & Brezilya & 2 & 0,04 & İrlanda & 1 & 0,19 \\
\hline Danimarka & 14 & 2,66 & Macaristan & 2 & 0,04 & Litvanya & 1 & 0,19 \\
\hline İsveç & 13 & 2,47 & İan & 2 & 0,04 & Malta & 1 & 0,19 \\
\hline Hollanda & 12 & 2,28 & Norveç & 2 & 0,04 & Nepal & 1 & 0,19 \\
\hline Çin & 6 & 1,14 & Polonya & 2 & 0,04 & Sirbistan & 1 & 0,19 \\
\hline Avustralya & 5 & 0,95 & Güney Kore & 2 & 0,04 & Birleşik Arap Emirlikleri & 1 & 0,19 \\
\hline Çek Cumhuriyeti & 4 & 0,76 & Türkiye & 2 & 0,04 & & & \\
\hline İsviçre & 4 & 0,76 & Arjantin & 1 & 0,02 & & $\mathbf{5 2 8}$ & $\mathbf{1 0 0 , 0 0}$ \\
\hline
\end{tabular}




\section{Onaylayicular}

Medya alanında üretilen içeriklerin birçoğu çeşitli şekillerde ödüllendirilmektedir. Filmler, diziler, belgeseller, müzikler, haberler, basın fotoğrafları, televizyon formatları gibi birçok içerik ve format -ki bunlar kültürel mallardır- çeşitli kuruluşlarca ödüllendirilerek medya kuruluşlarına ve medya profesyonellerine çeşitli formlarda (iktisadi, sosyal, kültürel, sembolik) sermaye yüklenebilmektedir. Oscar, Cannes, Golden Globes, British Academy of Film and Television Arts, Emmy, International Adana Film Festival gibi sinema ve televizyonculuk; Emmy, MTV Video Music Award, Eurovision Song Contest gibi müzik; The Pulitzer Prizes, Magnum Photography Awards, Sony World Photography Awards, Istanbul Photo Awards, World Press Photo Awards gibi fotoğrafçlık alanında ödül veren mekanizmalar, bu alanlarda üretilen kültürel ürünleri ödüllendirerek üreticilerine çeşitli formlarda sermaye kazandırmaktadır. Her seçimin bir bakış açısı, bir dünya görüşü ekseninde gerçekleştiği göz önünde tutulursa bu mekanizmaların seçim yoluyla sadece üreticileri ödüllendirmekle kalmadığı ve aynı zamanda mevcut durumu da onaylayarak/beğenerek son noktayı koyduğu söylenebilir. Bu nedenle bu mekanizmaların kimlerce kurulduğu ve aktörlerinin kimler olduğu önemlidir.

Gazetecilik, bilim ve sanat alanları gibi kültürel üretimin alanına dönüşmüştür (Myles, 2010, s. 29). Hatta Bourdieu'ye göre (1998a, s.56) gazeteciler, kültürel üretimi ele geçiren gazetecilik alanının kontrolüne girmişlerdir. Kuşkusuz Bourdieu sosyolojisinde medya, kültürel üretim alanına denk düşer. Hatta günümüzde televizyon başta olmak üzere medya bu alanı neredeyse tümüyle denetimine almıştır (Bourdieu, 1998a, 2010). Bu nedenle gazetecilik alanının birer parçası olan foto muhabirleri mesleklerini icra ederken kültürel bir üretim gerçekleştirirler, yani kareledikleri fotoğraflar onların başarısını temsil eden ve onlara sermaye yükleyen birer kültürel emtiadır. Bourdieu, kültürel sermayeyi kendi içerisinde üç forma ayırır. Bu sermaye ilkinde, düşüncenin ve bedenin uzun dönemli hazırlık biçiminde somutlaştırılması durumunda var olur. İkincisinde, kitaplar, resimler, sözlükler, araçlar, makineler gibi kültürel mallar biçiminde nesneleştirilmesi durumunda, üçüncüsünde ise eğitim dereceleri gibi kurumsallaştırılması durumunda bulunur (1986, s. 243). Ödüllü fotoğraflar, bedenin yeteneğine göndermede bulunması açısından somutlaştırılmış; fotoğrafçının bir kurum 
tarafından yetkilendirilmesinden dolayı kurumsallaştırılmış ve temel olarak kültürel bir emtia oldukları için nesneleştirilmiş kültürel sermaye başlığ altına konumlanırlar. Ayrıca beraberinde üreticisine iktisadi, sosyal ve sembolik sermaye de kazandırırlar. Çünkü tüm sermaye türleri birbirine çevrilebilirlik özelliği taşırlar (Bourdieu, 1986, s. 252-254). Foto muhabirleri tarafından üretilen kültürel mallar (fotoğraflar), alanın kültürel üretim manttğıyla ne kadar uyumluysa o derecede diğer sermaye türlerine çevrilebilirlik özelliği gösterirler. Özetlemek gerekirse karelenen fotoğrafların medya kuruluşlarınca yayınlanması photo-journalistin kültürel üretimde başarılı olduğu anlamına gelir ve beraberinde foto muhabirine (ücret olarak) iktisadi sermaye, (ilişkilerinin genişlemesi olarak) sosyal sermaye, (alanda saygınlık kazanması olarak) sembolik sermaye yüklenir. Bu sürecin dışında başka bir mekanizmanın devreye girerek, ayn kültürel üretime, tüm sermaye türlerinden ikincil bir yükleme yapması mevcut kültürel üretimi tümüyle kutsamak demektir. İşte WPP gibi kuruluşlar, ikincil ve son sermaye yükleyicilerdir, tabiri caizse son noktayı koyuculardır, yani kültürel üretimin başarısinin teminatıdırlar.

Ödül mekanizmaları, foto muhabirlerini kültürel üretimleri üzerinden tüm sermaye türlerinde güçlü konuma getirilebilmektedir. Foto muhabirlerinin üretimlerini pekiştiren bir mekanizma olarak 10.000 Euro gibi iktisadi bir sermaye, ilişkiler ağını genişletmesi gibi sosyal bir sermaye, saygınlık gibi sembolik bir sermaye yükleyen WPP, böylece foto muhabirlerini kutsamakta ve anlatıyı da onaylamaktadır. Gerek basın fotoğrafçılığı gerekse WPP alanının habitusu/iş yapma pratikleri tarihsel süreçte yine foto muhabirlerince tayin edildiğinden, kutsanmak ve onanmak isteyen foto muhabirleri objektifi neye yönelteceğinin, yani alanda neyin değerli olduğunun bilincindedirler. Bourdieu (1989, s. 22), kültürel üretimi gerçekleştirenlerin, diğer sermaye türlerini daha fazla önceleyen kültürel üretimlere yöneldiğini işaret etmektedir. Buradaki amaç, kültürel mallar aracılığıyla tüm sermaye türlerinde giderek kuvvetlenmek ve sonunda soyut olan o sembolik güce ulaşmak ve böylece alanda söz sahibi olmaktır. Bu nokta önemlidir, çünkü Bourdieu, sembolik güçle asıl amaçlananın, dünyayı şekillendirmek olduğunu vurgulamaktadır.

Tüm mesleklerde olduğu gibi foto muhabirliğinde de belirli amaçlara ulaşma, sembolik güç edinme, iktisadi ve sosyal sermaye biriktirme çabası mevcuttur. Bourdieu (1998a, s.56) gazetecilerin tümünün, kültürel üretimi 
eline geçiren gazetecilik alanına bağımlı hale geldiklerini söyler. Ama sermayenin insanlığın en acı durumları üzerinden biriktirildiği gerçeği, içinden çıkılamaz bir tartışma başlatmaktadır. World Press Photo Kuruluşu, basın fotoğrafçılığı alanındaki kültürel üretim sürecinin onaylayıcısıdır. Alanda neyin değerli olup olmadığına karar veren ve beğeni kriterleri tarihsel süreçte belirlenmiş bir mekanizmadır. Habitus bellidir ve gördügü anda neyin değerli olduğunu anında bilir. Yukarıdaki bölümlerde sıklıkla değindiğimiz gibi olumsuzluk, şiddet, savaş, kan, kavga, terör, kaza, doğal afet vb. birçok durum, alanda kültürel malın değer ölçütüne dönüşmüş durumdadır. Durumu tespit edenlerin, büyük oranda Avrupalı ve Kuzey Amerikalı olduğu görülmektedir. Durumu onaylayanların mevcut görünümü şöyle özetlenebilir:

WPP'nin 63 yıllık sürecinde 440 kişi jüri üyesi olarak görev yapmıştır. Jüri üyelerinin uyruklarını gösteren liste Tablo 14'de kıtalara göre sayılarını ve yüzdelerini gösteren veriler de Tablo $15^{\prime}$ te yer almaktadır.

Tablo 14. Jüri üyelerinin uyruklarına göre dağılımı

\begin{tabular}{|c|c|c|c|c|c|c|c|c|c|c|c|}
\hline Uyruk & $\mathbf{n}$ & $\%$ & Uyruk & $\mathbf{n}$ & $\%$ & Uyruk & $\mathbf{n}$ & $\%$ & Uyruk & $\mathbf{n}$ & $\%$ \\
\hline ABD & 61 & 13,86 & Brezilya & 6 & 1,36 & Şili & 3 & 0,68 & Gana & 1 & 0,23 \\
\hline Holanda & 54 & 12,27 & Çin & 6 & 1,36 & İran & 3 & 0,68 & Yunanistan & 1 & 0,23 \\
\hline Birleşik Krallık & 41 & 9,32 & Hindistan & 6 & 1,36 & Nijerya & 3 & 0,68 & Endonezya & 1 & 0,23 \\
\hline Almanya & 39 & 8,86 & İsveç & 6 & 1,36 & Türkiye & 3 & 0,68 & Irak & 1 & 0,23 \\
\hline Fransa & 36 & 8,18 & İsviçre & 6 & 1,36 & Finlandiya & 2 & 0,45 & Fildişi Sahilleri & 1 & 0,23 \\
\hline Rusya & 27 & 6,14 & Macaristan & 5 & 1,14 & Hong Kong & 2 & 0,45 & Ürdün & 1 & 0,23 \\
\hline İtalya & 14 & 3,18 & Meksika & 5 & 1,14 & Lübnan & 2 & 0,45 & Pakistan & 1 & 0,23 \\
\hline Japonya & 12 & 2,73 & Singapur & 5 & 1,14 & Norveç & 2 & 0,45 & Filistin & 1 & 0,23 \\
\hline Güney Afrika & 11 & 2,50 & Çekoslavakya & 4 & 0,91 & Peru & 2 & 0,45 & Portekiz & 1 & 0,23 \\
\hline İspanya & 10 & 2,27 & Danimarka & 4 & 0,91 & Filipinler & 2 & 0,45 & Sirbistan & 1 & 0,23 \\
\hline Avustralya & 8 & 1,82 & Avusturya & 3 & 0,68 & Cezayir & 1 & 0,23 & Güney Kore & 1 & 0,23 \\
\hline Polonya & 8 & 1,82 & Bangladeş & 3 & 0,68 & Azerbaycan & 1 & 0,23 & Yugoslavya & 1 & 0,23 \\
\hline Arjantin & 7 & 1,59 & Kamerun & 3 & 0,68 & Kolombiya & 1 & 0,23 & Zimbabve & 1 & 0,23 \\
\hline Belçika & 6 & 1,36 & Kanada & 3 & 0,68 & Ekvador & 1 & 0,23 & TOPLAM & 440 & 100 \\
\hline
\end{tabular}

Dünyanın yakın tarihine ş̧ık tutan bu yarışmanın onaylayıcıları nicel olarak incelendiğinde ABD uyruklu olanların ilk sırada yer aldığı görülmektedir. WPP, Hollanda merkezli bir organizasyon olmakla birlikte ABD, 61 jüri üyesi ile Hollanda'yı geride bırakmıştır. Bu sonuç ABD'nin uluslararası iletişim akışında eyleyen rolünü ve otoritesini tekrardan doğrulamaktadır. ABD'yi 54 üye ile Hollanda, 41 üye ile Birleşik Krallık, 39 üye ile Almanya, 36 üyeyle Fransa izlemektedir. ABD ve Batı Avrupa ülkelerinden onaylayıcılar ağırlıklı biçimde fotoğraflar üzerinde belirleyici olurken, dünyanın 
farklı coğrafyalarından jüri üyelerinin sembolik düzeyde kattlımlarının olduğu anlaşılmaktadır.

Tablo 15 incelendiğinde Avrupa'nın $244(\% 55,45)$ jüri üyesi sayısıyla ilk sırada, Asya'nın 78 (\%17,73) ile ikinci sırada, Kuzey Amerika'nın 64 $(\% 14,55)$ ile üçüncü sırada yer aldığı anlaşılmaktadır. Diğer bölgelerdeki jüri üyesi sayıları 5-20 aralığındadır. Fotoğrafların \%64,87'sinin Asya, Africa, Orta ve Güney Amerika'da karelenmesine rağmen jürilerin \%71,82'sinin Avrupa, Kuzey Amerika ve Avusturalya'dan olması seçim sürecinde dahi dengesiz bir temsilin olduğunu göstermektedir. Başka bir anlatımla WPP üzerinden okuduğumuz dünya imgesinin sadece tespitçileri değil aynı zamanda onaylayıcıları da büyük oranda Avrupalı, Kuzey Amerikalı ve Avusturalyalıdır. Durumu onaylayan ve durumu tespit edene iktisadi ve sembolik güç başta olmak üzere çeşitli formlarda sermaye yükleyen WPP, uluslararası medya/gazetecilik alanıla paralel bir habitusa sahiptir. Bu süreçteki mekanizmalar, birbiriyle tutarlı bir işleyişle dünyayı senkron bir şekilde kendi bakış açılarından imgelemektedirler.

Tablo 15. Jüri Üyelerinin Kıtalara Göre Dağılımı

\begin{tabular}{lll}
\hline Kita & n & \% \\
\hline Avrupa & 244 & 55,45 \\
\hline Asya & 78 & 17,73 \\
\hline Kuzey Amerika & 64 & 14,55 \\
\hline Afrika & 21 & 4,77 \\
\hline Güney Amerika & 20 & 4,55 \\
\hline Avustralya & 8 & 1,82 \\
\hline Orta Amerika & 5 & 1,14 \\
\hline
\end{tabular}

\section{Sonuç}

Bu çalışma 63 yıllık tarihsel geçmişiyle dünya genelinde yüksek bir prestije sahip olan WPP'nin çeşitli kategorilerindeki ödüllü fotoğraflarını çok yönlü incelemelere tabi tutmuştur. İncelemeler sonucunda Batı merkezli ve tek yönlü bir akışa sahip olan uluslararası basın fotoğrafçllı̆̆ alanının, liberal/ana akım medyanın haber üretim pratikleriyle paralel özellikler gösterdiği ve bu nedenle de acl, hüzün, şiddet, olumsuzluk gibi durumlar anlatan içeriklere değer yüklediği sonucuna varılmıştır. Uluslararası basın fotoğrafçılığı alanının pratiklerinin başta Kuzey Amerikalı ve Batı Avrupalı olmak üzere Batılı aktörler tarafından inşa edildiği ve sürdürüldüğü ama bu aktörlerin kültürel üretimlerini ve böylece de sermayelerini büyük oranda Asya ve Afrika başta 
olmak üzere dünyanın gelişmemiş ya da gelişmekte olan kısmen sorunlu coğrafyalarında biriktirdiği saptanmıştır. Başka bir anlatımla ödül alan fotoğrafçların, bu fotoğrafları yayınlayan medya kuruluşlarının ve ödüle layık gören jüri üyelerinin büyük oranda Kuzey Amerika ve Avrupa'dan (özne); ödül alan şiddet ve olumsuz içerikli fotoğrafların ise büyük oranda Africa ve Asia başta olmak üzere dezavantajlı coğrafyalardan (nesne) olduğu görülmüştür.

Fotoğraflar konularına göre değerlendirildiğinde foto muhabirlerinin, savaş, açlık/yoksulluk, hastalık, mültecilik, toplumsal hareketler, terör gibi olumsuzluk barındıran konulara eğilimli oldukları anlaşılmıştır. Bu da yine alanın bir özelliği olarak yorumlanabilir. Bu alanın, genel olarak Asya'yı savaşla, Afrika'yı açlık/yoksulluk/hastalıkla, Güney Amerika'yı toplumsal hareketlerle, Orta Amerika'yı terör ve çetelerle, Kuzey Amerika'yı siyasetle ve Avrupa'yı ise siyaset ve gündelik yaşam gibi konularla özdeşleştirerek söz konusu bölgelere ilişkin imgeler ürettiği görülmüştür. WPP'den ödül almayı amaçlayan bir foto muhabiri, objektifini hangi coğrafyada neye yönelteceğini bilmektedir. Çünkü alanın kuralları tarihsel süreçte belirli kurallar doğrultusunda inşa edilmiştir. Foto muhabirine düşen ise oyunu bu kurallar doğrultusunda başarılı bir şekilde oynayabilmektir.

Çalışmada ABD'nin uluslararası politikalarının bir yansıması olarak medyasının da etkin bir role sahip olduğunu destekleyen verilere ulaşılmıştır. Özellikle medya kuruluşları, medya profesyonelleri açısından ulaşılan veriler, uluslararası iletişim akışını yöneten merkez ülkenin ABD olduğunu ortaya koymuştur. WPP'de ödül alan fotoğrafların 264'ünün ABD kökenli kuruluşlarca servis edildiği görülmüş̧ür. Yanı sıra ABD uyruklu fotoğrafçıların yalnızca kendi kıtalarında değil, dünyanın tüm coğrafyalarında gerçekleşen olayların saptayıcı aktörleri olarak rol oynadığı sonucuna varılmıştır. ABD'nin gerek ulusal gerekse uluslararası alandaki müdahaleci ama müdahaleye kapalı politik anlayışı ve uygulamalarının, medyası için de geçerli olduğu söylenebilir. Şöyle ki, ABD’de karelenen ve ödül alan 67 fotoğrafın 58 'i yine ABD uyruklu fotoğrafçllarca çekilmiştir. Diğer 9 fotoğraf ise kültürel, siyasal ve tarihsel ortaklığı bulunan Avrupalılar tarafından karelenmiştir. Bu da ABD'nin medya politikaları açısından oldukça kapalı ve korunaklı bir tutum sergilediği şeklinde yorumlanabilir. Bu veriler, alanın pratiklerinin büyük ölçüde $\mathrm{ABD}$ tarafından şekillendirildiği/şekillendirilmeye devam ettiği şeklinde okunabilir. 
Fotoğrafları ödüllendirerek öncelikle foto muhabirlerine ve bu muhabirlerin bağlı oldukları yayıncı kuruluşlara özellikle iktisadi ve sembolik sermaye yükleyen WPP'nin değer algısının liberal/ana akım medyanın değer algısıyla paralellik gösterdiği dikkat çekmiştir. Hollanda merkezli olan bu kuruluşun, Batı medyasının yeniden inşa ettiği/inşa etmeye çalıştığı dünya imgesini destekleyen bir politika doğrultusunda foto muhabirlerinin kültürel üretimlerine iktisadi ve sembolik sermaye yüklediği görülmüştür.

Özetle bu çalışmada oluşturulan dörtlü aşamadan üçünün, yani keşifçilerin, yayıncların ve onaylayıcıların aynı habitus doğrultusunda kültürel üretim gerçekleştirdikleri ve böylece kendi bakış açlarından büyük oranda olumsuz Asya, Afrika, Orta ve Güney Amerika; kısmen olumlu Kuzey Amerika ve Avrupa imgesi inşa ettikleri sonucuna ulaşılmıştır. Avustralya ile ilgili fotoğrafın sayıca az olmasının, bu kıtaya ilişkin yorumlarımızı sınırlandırdığın da belirtmekte fayda vardır. 


\title{
EXTENDED ABSTRACT
}

\section{The World Image Produced by International Press Photography: A Reading Through the Awarded Photos by World Press Photo Foundation}

\author{
Onur Dursun - Filiz Yıldız - Serkan Bulut \\ Cukurova University
}

This study referred to the Bourdieu's notions of "field", "habitus" and partly "economic capital, cultural capital, social capital and symbolic capital/power" in order to probe the photos awarded by WPP, partially independent from the attitudes of photo-journalists and, therefore, to evaluate the situation as the practices of the international media/journalistic field related to international economic and political policies. This study focuses on the existing image of the world produced/reproduced through the practices of the international photo-journalistic field, namely through the awarded photos from the WPP. To produce this image of the world, the awarded photos should trace some processes interrelated each other: (1) Attitude, Subjects and Geographies); (2) Discoverers; (3) Releasers; and finally, (4) Attestors/WPP. This study investigated the 'subject discussed in the article' under the four successive phases as described.

Emphasis on Negative Attitude: The attitude presented by 574 photos was evaluated in three categories as positive, negative and neutral. As a result of this evaluation, it was concluded that 414 (72.13\%) photos were negative, $94(16.38 \%)$ were positive and $64(11,50 \%)$ were neutral (see Table2 for negative attitude).

Emphasis on Violence: The results of the coding as "yes" or "no" indicate that 341 out of 574 photos contain violence images and 233 out of them do not.

Subjects and Geographies: As a result of the analysis, photos were encoded under 14 categories. As understood from results, the category of the War/Civil War and Internal Disturbance War is the highest with 162 photos in all the categories. In this category, Asia is in the first place with a rate of $45,11 \%$ in itself. Asia with 102 war photos out of 162 has a very high ratio of $65,43 \%$ and is the first in general. Asia leads the list due to the quantitative 
lack of Africa continent's photos in grand total for the Famine/Poverty Category. 81 encodings were integrated into the Daily Life category within this scope. 28 of those photos were taken in Asia, 20 were taken in Europe, and 13 were taken in North America. 78 of the photos questioned are encoded into the Political Actors Category. 24 of those photos (30.77\%) were taken in Asia, 21 (26.92\%) were taken in North America, and 20 (25.64\%) were taken in Europe. There are 67 photos in the Ceremony Category, $27(40.30 \%)$ of which were taken in Asia, 26 (38.81\%) were taken in Europe and 5 (7.46\%) were taken in North America. 62 total photos were encoded into the Migration/Refugees Category, 26 of which were taken in Asia and 21 were taken in Africa. 60 total photos were encoded into the Disease/Disability Category. $19(31.67 \%)$ of those photos were taken in Africa, 18 (30.00\%) in Asia and 12 $(20.00 \%)$ were taken in North America. 43 of the photos were encoded into the Social Movements Category. 22 (51.16\%) of those were taken in Asia, 8 $(18.60 \%)$ were taken in Europe and $5(11.63 \%)$ were taken in North America.

Discoverers: Analyzing the information regarding the photographers establishing the second phase of our study remarks that Europe and North America are quantitatively predominant by a landslide. The fact that 165 photos out of 574 were taken by American photographers indicates the expanding dominance of the USA over all the territories in the world and its transnational power. Although Asia has the highest portion of the analyzed photos, only $34.89 \%$ of 235 photos taken in this continent were taken by Asian photographers. The percentage of the photographers documenting the facticity of their own land in Africa is $9.09 \%$ of the awarded 77 photos taken there.

Releasers: International media companies decide their agenda topics, their content and presentation methods through taking these sorted filters into account. $90.49 \%$ of the photos investigated were published by American and European media companies. In other words, global perception, in particular for Asia and Africa, is built via Western media agencies.

Attestors: Analyzing quantitatively the attesting authorities of this contest that sheds a light on the recent history of the globe reveals that USA citizens take the first place. Although WPP is a Dutch company, the USA leaves the Netherlands behind with 61 jury members. This result reconfirms the functional role and domination of the US in communication streaming. 
This study focuses on the awarded photos in various categories of WPP which has a worldwide prestige with a history of 63 years. It has been concluded that international photo-journalistic field practices are built and proceeded by Western agencies, who are especially North American and West European; however, these agencies collect their cultural productions and thus their capitals in partially problematical underdeveloped and developing countries of the globe, in particular Asia and Africa.

\section{Kaynakça / References}

Arsenault, A. H. ve Castells, M. (2008). The structure and dynamics of global multimedia business networks. International Journal of Communication. 2 (43), 707748.

Bourdieu, P. (1984). Distinction, a social critique of the judgement of taste. (R. Nice, Çev.). Massachusetts: Harvard University Press

Bourdieu, P. (1986). The forms of capital. J. Richardson (Ed.). Handbook of Theory and Research For The Sociology of Education içinde (s. 241-258). New York: Greenwood

Bourdieu, P. (1989). Social space and symbolic power. Sociological Theory, 7 (1), 14-25.

Bourdieu, P. (1998a). On television. (P. P. Ferguson, Çev.). New York: The New Press.

Bourdieu, P. (2005). The political field, the social science field, and the joumalistic field. R. Benson \& E. Neveu (Eds.). Bourdieu and the journalistic field içinde (s. 29-47). Polity Press.

Bourdieu, P. (1998b). Practical reason / on the theory of action. California: Stanford University Press.

Bourdieu, P. (1995). The rules of art / genesis and structure of the literary field. California: Stanford University Press.

Bourdieu, P. ve Wacquant, L. J. (2014). Düşünümsel bir antropoloji için cevaplar. (N. Ökten, Çev.). İstanbul: İletişim Yayınları.

Butler, J. (1999). Gender trouble: Feminism and the subversion identity. New York: Routledge.

Calhoun, C. (2007), Bourdeu sosyolojisinin ana hatları. (G. Çeğin Çev.). Ocak ve Zanaat içinde (s. 77-129). G. Çeğin, E. Göker, A. Arl, Ü. Tatlıcan (Ed.). İstanbul: Illetişim Yayınları.

Chomsky, N. (1989). Necessary illusions: Thought control in democratic societies. UK: Pluto Press. 
Çelenk, S. (2010). Kadınların medyada temsili ve etik sorunlar. B. Çaplı ve H. Tuncel (Ed). Televizyon Haberciliğinde Etik içinde (s. 229-236). Ankara: Fersa Matbaac1lik.

Dursun, O. (2014). Batinnn egemen 'kötü-öteki-doğu' düşüncesinin pekiştirildiği bir alan: Dünya basin fotoğrafları kurulusu, yllın fotoğrafı kategorisi üzerine bir analiz. İstanbul Üniversitesi İletişim Fakültesi Dergisi, 47, 19-55.

Fishman, M. (1988). Manufacturing the news. University of Texas Press.

Forbes. (2015). The World's biggest media companies of 2015. 15 Ağustos 2020 tarihinde https://www.forbes.com/pictures/eimi45gdej/no-1-british-skybroadc/\#4f689d60481d adresinden erişildi.

Foucault, M. (1981). The order of discourse. R. Young (Ed.) Untying The Text: A PostStructuralist Reader. Boston: Routledge \& Kegan Paul.

Galtung, J. ve Ruge, M. H. (1965). The structure of foreign news: The presentation of the Congo, Cuba and Cyprus crises in four Norwegian newspapers. Journal of Peace Research, 2(1), 64-90.

Gans, H. J. (2003). Democrasy and the news. New York: Oxford University Press.

Gencel Bek, M. (2010). Karşlaştırmalı perspektiften Türkiye'de medya sistemi, Mülkiye, 34(269), 101-125.

Grabe, M. E., ve Kamhawi, R. (2006). Hard wired for negative news? Gender differences in processing broadcast news. Communication Research, 33(5), 346-369.

Hallin, D. C. (1986). The "uncensored war": The media and Vietnam. New York: Oxford University Press.

Hallin, D. C., ve Mancini, P. (2004). Comparing media systems: Three models of media and politics. Cambridge University Press.

Hamelink, C. (2015). Global communication. UK: Sage Publications.

Happer, C. and Philoap, G. (2013). The role of the media in the construction of public belief and social change. Journal of Social and Political Psychology, 1(1), 321-336. (doi:10.5964/jspp.v1i1.96.).

Hegel, G. W. F. (2015). Tarihte akıl. (Ö. Sözer, Çev.). İstanbul: Kabalcı Yayıncllı

Herman, E. S., ve Chomsky, N. (2008). Manufacturing Consent: The political economy of the mass media. London: Bodley Head.

İnal, A.M. (1994). Haber üretim sürecinde farklı iki yaklaşım. İlef Ylllık' 93, 155-177.

Julie Firmstone (2012) European Media: structures, politics and identity, Journalism Practice, 6(3), 424-426, DOI: 10.1080/17512786.2011.650879.

Kant, I. (1917). Perpetual peace: A philosophical essay. (M. C. Smith, Çev.). London: George Allen \&Unwin. 
Karim, K. H. (2003). Making sense of the "Islamic peril": Journalism as cultural practice. B. Zelizer ve S. Allan (Eds.). Journalism after September 11 içinde (119-134). Routledge.

Kate, M. (2018). Images of Africa in World Press Photo. Marta Iñiguez de Heredia \& Zubairu Wai (Ed.). Recentering Africa in International Relations Beyond Lack, Peripherality, and Failure içinde (s. 87-119).

Kaya, A. (2007). Pierre Bourdieu'nün pratik kuramının kilidi: Alan kavramı. G. Çeğin, E. Göker, A. Arlı, Ü. Tatlıcan (Ed.). Ocak ve Zanaat içinde (s.397-419). İstanbul:Iletişim Yayınları, İstanbul.

Lippmann, W. (1922). Public opinion. Transaction Publishers.

McCombs, M. E., ve Shaw, D. L. (1993). The evolution of agenda-setting research: twenty-five years in the marketplace of ideas. Journal of Communication, $43(2), 58-67$

McCombs, M.E., ve Shaw, D.L. (1972). The agenda-setting function of mass media. Public Opinion Quarterly, 36, 176-187.

McCombs, M. (2005). A look at agenda-setting: Past, present and future. Journalism Studies. 6(4), 543-557. doi:10.1080/14616700500250438

Mughan, A., ve Gunther, R. (2000). The media in democratic and nondemocratic regimes: A multilevel perspective. In R. Gunther ve A. Mughan (Eds.) In Democracy and the media: A comparative perspective (s.1-27). Cambridge University Press,

Myles, J. F. (2010). Bourdieu, language and the media. Palgrave Macmillan.

Nagel, J. (1998). Masculinity and nationalism: gender and sexuality in the making of nations. Ethnic and Racial Studies, 21(2), 242-269, DOI: 10.1080/014198798330007

Norris, P. (2000). A virtuous circle: Political communications in postindustrial societies. Cambridge University Press.

Östgaard, E. (1965). Factors influencing the flow of news. Journal of Peace Research, 2(1), 39-63.

Postman, N. (2006). Amusing ourselves to death: Public discourse in the age of show business. Penguin.

Poyraz, B. (2002). Haber ve Haber Programlarnnda İdeoloji ve Gerçeklik. Ankara: Ütopya Yayınları.

Płudowski, T. (2006). International Communication Flow: Global Media's Performance. Global Media Journal-Polish Edition, 1(1), 1-10.

Said, E. W. (1997). Covering Islam: How the media and the experts determine how we see the rest of the world. Random House 
Said, E.W. (2003). Orientalism. London: Penguin Books.

Sancar, S. (2014). Türk modernleşmesinin cinsiyeti: erkekler devlet, kadınlar aile kurar. İstanbul: İletişim Yayınları.

Schechter, D. (2003). Embedded: Weapons of mass deception: How the media failed to cover the war on Iraq. Prometheus Books.

Schudson, M. (1989). The sociology of news production. Media, culture E society, 11(3), 263-282.

Schudson, M. (2010). Autonomy from What? R. Benson ve E. Neveu (Eds.) Bourdieu and the journalistic field içinde (s. 49-63). Cambridge: Polity Press.

Shoemaker, P. J. (1991). Gatekeeping. Communication Concepts 3. Newbury Park. Sage. Internetnachweise: oV: LEO. Link everything online. http://dict. leo. org, 28, 2003.

Snoubar, Y. ve Duman, N. (2016). Impact of wars and conflicts on women and children in Middle East: Health, psychological, educational and social crisis. European Journal of Social Sciences Education and Research, 6(2), 72-76.

Thussu, D. K. (2000). International communication, continuity and change. New York: Oxford University Press.

Tuchman, G. (1978). Making news: A study in the construction of reality. London: Collier MacMillian Publication.

Warf, B. (2007). Oligopolization of global media and telecommunications and its implications for democracy. Ethics Place and Environment, 10(1), 89-105.

Yaylagül, L. (2006). Kitle iletişim kuramları: Egemen ve eleştirel yaklaşımlar. Ankara: Dipnot Yayınları.

Yıldız F. ve Aydoğmuş Ördem, Ö. (2018). Childhood 1deology in the early Turkish Republican era. Journal of Politics and Law, 11, 82-97.

Zarzycka, M., ve Kleppe, M. (2013). Awards, archives, and affects: tropes in the World Press Photo contest 2009-11. Media, Culture E Society. 35(8), 977-995.

\section{Kaynakça Bilgisi / Citation Information}

Dursun, O., Yıldız, F. ve Bulut, S. (2020). Uluslararası basın fotoğrafçılı̆̆ı alanında acının araçsallaştırılması: WPP ödüllü fotoğraflar üzerinden bir okuma. OPUS-Uluslararası Toplum Araştırmaları Dergisi, 16(32), 5034-5074. DOI: 10.26466/opus.798661 